The Catholic University of America, Columbus School of Law

CUA Law Scholarship Repository

Scholarly Articles and Other Contributions

Faculty Scholarship

2007

\title{
The Quest for Legitimacy in American Administrative Law
}

Marshall J. Breger

The Catholic University of America, Columbus School of Law

Follow this and additional works at: https://scholarship.law.edu/scholar

\section{Recommended Citation}

Marshall J. Breger, The Quest for Legitimacy in American Administrative Law, 40 ISRAEL L. REV. 72 (2007).

This Article is brought to you for free and open access by the Faculty Scholarship at CUA Law Scholarship Repository. It has been accepted for inclusion in Scholarly Articles and Other Contributions by an authorized administrator of CUA Law Scholarship Repository. For more information, please contact edinger@law.edu. 


\title{
THE QUEST FOR LEGITIMACY IN AMERICAN ADMINISTRATIVE LAW
}

\author{
Marshall J. Breger*
}

In the United States, administrative law suffers from a perceived lack of legitimacy largely due to a lack of democratic accountability or what some have called a democratic deficit. These misgivings stem, in part, from a deep-seated American distrust of bureaucracy. This Article examines how the quest for legitimacy has led practitioners (and theorists) of administrative law to undertake four interrelated projects: the Accountability Project, the Rationality Project, the Transparency Project, and the Participatory Project all designed to create a substitute or shadow form of democratic legitimacy.

Through an examination of these projects, I clarify how they try to address the democratic deficit, and whether they effectively do so. Specifically, this article investigates the impact of judicial review, informal rule-making, increased access to information, and public participation as efforts to meet the legitimacy challenge. Moreover, it disputes the contention that the pursuit of democratic legitimacy is less consequential for administrative law than the need for bureaucratic rationality, by illustrating that bureaucratic rationality is but one component of a larger scheme intended to serve as a functional substitute for legitimacy. At bottom, because Americans do not share the fondness for the technocratic model displayed by many other legal systems, legitimacy projects have an enduring place in American administrative law.

\section{Introduction}

Administrative law is often seen as the stepchild of public law. In the United States, at least, the excitement centers around constitutional law, where visions of grand theory and public policy often clash.

- Professor of Law Columbus School of Law, Catholic University of America.

This is a revised and expanded version of a lecture delivered at the Fulbright Israel/USIEF $50^{\text {th }}$ Anniversary Symposium, the Hebrew University, Jerusalem, Jan 29-30, 2006. Some portions of this paper are drawn from $A$ Short Tour of American Administrative Law, published in 2 EsTUDIS EN Memoria de Professor Doutor Antonio Marques Dos Santos 759-779 (2005).

My thanks to Linda C. Bailey and Sandra Safro for their research assistance and Jeffrey Lubbers, Heather Elliott, and Peter B. Rutledge for their careful review of the manuscript. 
Too often we administrative lawyers have been lonely-never present at the myriad constitutional law reform conferences held in Bellagio and Aspen to advise newly-emerging democracies on how to draft constitutions and protect civil liberties.

Nonetheless, administrative law provides a unique perspective to understand the relationship between the citizen and the state. It is a relationship based on everyday life, be it the desire for a fishing license, a question of old age pensions, or safety in the workplace. And as I will argue, this relationship raises basic problems of democratic theory.

Administrative law in the United States suffers from a perceived democratic deficit. ${ }^{1}$ By this, I mean the concern that bureaucrats - the denizens of the administrative state-lack the direct political legitimacy that comes from the discipline of popular elections. True, there is indirect legitimacy: in the American political system, the agents of bureaucracy are appointed in the main by elected officials. But the fit is not exact. The very nature of the administrative state leaves issues freighted with policy significance to the discretion of administrators, who hew to a "technocratic model" rather than a "populist" approach. ${ }^{2}$ In this paper, I hope to explain some of the efforts made in American administrative law to compensate for this perceived lack of political legitimacy.

Before doing so, I need to state a caveat. Unlike other panelists in this symposium my discussion is not comparative, but rather is focused largely on the American scene.

1 In that regard administrative law suffers from the same "counter majoritarian" problem so often raised as a challenge for judges in Constitutional interpretation. The problem was most famously set forth in Alexander M. Bickel, The Least Dangerous Branch 16-23 (1962). See also Mihui Pak, The Counter-Majoritarian Difficulty in Focus: Judicial Review of Initiatives, 32 CoLum. L. J. \& Soc. Probs. 237 (1999); Kenneth Ward, The Counter-Majoritarian Difficulty and Legal Realist Perspectives of Law: The Place of Law in Contemporary Constitutional Theory, 18 J.L. \& PoL. 851 (2002). But see Julian N. Eule, Judicial Review of Direct Democracy, 99 Y ALE L.J. 1503, 1531-32 (1990), who argues that Bickel erred in characterizing the problem with judicial review as "counter-marjoritarian" in nature. Instead, the more accurate description is that the problem is "counter-republican" by nature, a portrayal which better describes how the Framers designed American democracy: a representative system. Id.

2 Cass R. Sunstein, Laws of Fear: Beyond the Precautionary Principle 126-28 (2005). Sunstein urges deference to the technocratic approach recommending insulation of specialists from unjustified public fears, so that the government "respond[s] to [the] people's values, not to their blunders." See also Dan M. Kahan, Paul Slovic, Donald Braman, \& John Gastil, Fear of Democracy: A Cultural Evaluation of Sunstein on Risk, 119 HARV. L. REV. 1071, 1075 (2006)(reviewing Cass R. Sunstein, Laws of Fear: Beyond the Precautronary Princtrle (2005)), explaining that "distort[ed] risk perceptions have the largest impact on members of the lay public; [whereas] scientifically trained experts are less vulnerable to these influences ...." 
In my view, administrative law is one of the least likely areas of jurisprudence to be open to international influences. ${ }^{3}$ The reason is that administrative law concerns are deeply rooted in the unique structural arrangements of national legal systems and deeply influenced by a legal system's domestic political context. This is particularly true of American administrative law, whose principles are deeply embedded in the idiosyncrasies of American separation of powers law-what many have called the "structural constitution"4-as well as in the historical battle between the courts and the executive in the English common law. Thus, one must be careful in suggesting that one legal system draws on the jurisprudence of another. We must always remember that administrative law in America is not easily transported into foreign legal systems precisely because there are differences in the nature of the jurisprudence and the nature of the state in each system.

Of course, common problems may suggest - at least to the academic-common solutions. ${ }^{5}$ The sociology of bureaucracy is not limited to particular jurisdictions. But the notion of common problems needs to be carefully parsed. As Kenneth Anderson notes:

3 Tax law is another area where it is unlikely international influences will have much effect due to the "continuing vitality" of the revenue nule. Gary B. Born \& Peter B. Rutledge, International Civil Litigation in United States Courts 1034-36 (2007)(citing Her Majesty the Queen in Right of the Province of British Columbia v. Gilbertson, 597 F.2d 1161 (9th Cir. 1979)).

4 "The genius of the American Constitution lies in its use of structural devices to preserve individual liberty. Checks and balances, separation of powers, and federalism all combine to create opportunities for '[a]mbition . to counteract ambition'. . "Steven G. Calabresi \& Kevin H. Rhodes, The Structural Constitution: Unitary Executive, Plural Judiciary, 105 HaRv. L. Rev. 1153, 1155 (1992); see also J. Harvey Wilkinson, The Structural Constitution, 104 CoLuM. L. REv. 1687 (2004).

5 The Scandinavians, for example, spawned the concept of the ombudsman (however variously applied world wide). See Walter Gellhorn, Ombudsman and OtHers: Citizens' Protectors in Nine Countries (1967); see also Linda C. Reif, The Ombudsman, Good Governance and the International Human Rights System 4-6 (2004); see Donald C. Rowat, The Ombudsman Plan: THE WorldWDe SpREAD OF AN IdEA 3-28 (1985).

Over thirty-five countries have used the American Freedom of Information Act as the model for their own legislation. John M. Ackerman \& Irma E. Sandoval-Ballesteros, The Global Explosion of Freedom of Information, 85 ADMIN. L. REv. 85, 111-12 (2006).

Lord Woolf, the Lord Chief Justice of England, referring to the Israeli legal system, has written of the "close relations between the legal systems of our countries," pointing out that it is in public and constitutional law issues that "the two countries have most in common." The Rt. Hon., The Lord Woolf, Lionel Cohen Lecture 2003: Constitutional Developments in a Common Law Jurisdiction, 37 IsR. L. REV. 5, 6 (2004). 
[C]ertain legal problems are "common" because they raise crossborder issues, such as settlement of water disputes or pollution between countries. One might also talk of "common" legal problems where the judiciary of one country might learn from the experience of another country's courts and their special techniques. France, for example, recently introduced a class action device, and it obviously and intelligently looked to comparative models. ${ }^{6}$

Indeed there is significant academic discussion of the concept of policy transfer or diffusion. ${ }^{7}$ The matter is extremely complex. Consider as one example the American approaches towards regulatory impact analysis (RIA) requiring cost-benefit analysis before the promulgation of regulations. There is substantial evidence that the EU has recently developed similar cost-benefit approaches. ${ }^{8}$ Are these parallel developments? Do they reflect policy transfer? Can there be diffusion without convergence? ${ }^{9}$ There can be little doubt that European academics, if not Brussels bureaucrats, were aware of American developments. Whether there was a causal connection is unclear.

But none of this has anything to do with causal relationships or indeed with the underlying connection between administrative law and a nation's jurisprudential ethos.

6 Kenneth Anderson, Foreign Law and the U.S. Constitution, 131 PoL'y Rev. 33, 40 (June \& July, 2005) available at http://www.policyreview.org/jun05/anderson.html (last visited July 9, 2006).

7 See David Dolowitz, Stephen Greenwold \& David Marsh, Policy Transfer: Something Old, Something New, Something Borrowed, But Why Red, White or Blue?, 52 ParliamentaRY AffalRS 719 (1999); David Dolowitz \& David Marsh, Who Learns What from Whom: a Review of the Policy Transfer Literature, 44 Pol. STud. 343 (1996); C. Bennett, What is Policy Convergence and What Causes it?, 21 BRIT. J. Pol. ScI. 215 (1991); see also David P. Dolowitz \& David Marsh, Learning from Abroad: The Role of Policy Transfer in Contemporary Policy-Making, 13 GovernanCE 5 (2000).

${ }^{8}$ For discussions of cost-benefit analysis in the EU, see Stephen M. Johnson, Economics v: Equit. II: the European Experience, 58 WASH. \& LeE L. Rev. 417, 446-449 (2001); Robert W. Hahn and Robert E. Litan, Counting Regulatory Benefits and Costs: Lessons for the U.S. and Europe, $8 \mathrm{~J}$. INT'L ECON. L. 473, 486-495 (2005). Recently, OIRA administrator John Graham, after "comparing notes" with European Commission officials wrote, "I was amazed at how serious the EU has become about regulatory reform." John D. Graham, The "Smart Regulation" Agenda: Progress and Challenges, 31 AduLN. \& REG. L. News 11, 14 (Winter 2006).

9 The answer as regards RIA in Europe is apparently yes, in that different EU countries appear to have adopted their own variant of RIA. See Claudio M. Radelli, Diffusion Without Convergence: How Political Context Shapes the Adoption of Regulatory Impact Assessment, 5 J. EUR. Pur. PoL'y 924 (2005). 


\section{American Administrative Law}

In my view, administrative law depends in huge measure on the jurisprudential culture of individual jurisdictions-what Baron Montesquieu so quaintly called, "The Spirit of the Laws." 10 Thus, for example, much of continental Europe has instinctively accepted "as inescapable"" and "unstoppable"12 Max Weber's paradigm classifying bureaucracy as an expression of high rationality in government administration. ${ }^{13}$ And for many in continental Europe such rationality in government was seen as far preferable to the vicissitudes of a potentate or the variability of vox populi.

For example, this is the case in France, where - in contrast to the US - "members of the Public... are much more likely to hold a hierarchical world view" leaving them more confident in the expertise of administrators and technocrats ${ }^{14}$ and more ready to defer to their judgments on regulatory policy. ${ }^{15}$ This deference to experts leads to the view that bureaucracy is good and that a centralized state is the natural approach to organizing society. ${ }^{16}$

${ }^{10}$ M. De Secondat Baron de Montesquieu, The Spirut of the Laws 6-7 (Thomas Nugent, trans. Robert Clarke \& Co. 1873).

"Max Weber, Economy and Society 223 (Guenther Roth \& Claus Wittich eds., Ephraim Fischoff, et al. trans., Bedminster Press 1968). See also Max Weber, Parliament and Government in Germany Under u New Political Order: Towards a Political Critique of Officialdom and the Party System, in Political Writings 156-57 (Peter Lassman \& Ronald Spears eds., 1994)(describing bureaucrats as "always and increasingly a person with professional training and a specialization").

1) Id. at 156.

${ }^{13}$ Id. at 159.

${ }^{14}$ Dan M. Kahan, Paul Slovic Donald Braman, \& John Gastil, Fear of Democracy: A Cultural Evaluation of Sunstein on Risk, 119 HARV. L. Rev. 1071 (2006). Kahan et al., supra note 2.

${ }^{15}$ See Paul Slovic, James Flynn, C.K. Mertz, Marc Poumadere, \& Claire Mays, Nuclear Power and the Public: A Comparative Study of Risk Perception in France and the United States, in CrossCultural Risk Perception: A SuRvey of Empirical Studies 87-89 (O. Renn \& B. Rohrmann eds., 2000). This cultural difference is said to explain the significant divergence between American and French regulatory policy on nuclear power and why $78-80 \%$ of energy production in France is nuclear despite findings that suggest the French perception of risks associated with nuclear power is as high or higher than Americans. Id. at 57; see also Uranium Information Centre Ltd., Nuclear Power in France: Briefing Paper 28, August 2006, available at http://www.uic.com.au/nip28.htm (last visited March 3, 2007).

16 See John C. Reitz, Political Economy as a Major Architectural Principle of Public Law, 75 TuL. L. Rev. 1121, 1128 (2001). See also Ezra N. Suleiman, Politics, Power and Bureaucracy in France-The Administratrve Elite 17-19 (1974). Although the sweeping decentralization reforms brought about by the Debré laws in 1982, at 730, codified in the General Code of Territorial 
Consider the story - likely apocryphal of "the French Minister of Education looking at his watch at three o'clock on a Monday afternoon and saying to a visitor: "At this moment pupils in year five of every French school will be studying Racine."'17 Accomplishing that degree of centralization takes a great deal of regulation.

For a short period of time from around the 1880s through the New Deal there was a strand of American thought that was similarly approving of bureaucracy. It was the age of science, of reverence towards experts and expertise. There was a belief as Woodrow Wilson put it, in the "science of administration," ${ }^{18}$ that politics could be divorced from governing. Wilson, I should note, held these views while a college professor. As candidate for President, he adopted a more skeptical view of what the British call "boffins." 19

Communities (Code Général des Collectivitiés Territoriales), and recently amended by Law No. 2004-809 of August 13, 2004, J.O., August 17, 2004, at 14,545. This recent modification expands local authority in fields such as economic development, zoning, tourism, vocational training, infrastructure, environmental protection, ports, solid waste, health, education, culture, sports, heritage, performing arts training, and also offers a number of institutional clarifications.

${ }_{17}$ Anne Corbett, Free and Compulsory: Republican Values in French Education, in EDUCATION $\mathbb{N}$ France: ContinutTy and Change IN the MitTerRand Years 1981-1995 1 (Anne Corbett \& Bob Moon eds., 1996). For evidence of the centralization of French education, see also Kathryn M. AndersonLevitt, Regine Sirota \& Martine Mazurier, Elementary Education in France, 92 ElemENTARY ScH. J. 343, 343, 345-348 (1968). However, since approximately 1982 significant steps towards decentralization have been taken. See Ketleen Florestal \& Robb CoOper, DeCENTRalization of EducATION: Legal Issues 18-19 (1997); Hans N. Weiler, Comparative Perspective on Educational Decentralization: An Exercise in Contradiction?, 12 Educ. Evaluation \& Pol'y ANalysis 433, 440-41 (1990); Sarah Elzas, Unrest in Education in France: Teachers on Strike, Educ. UPDATE ONLINE, July 2003, available at http://www.educationupdate/archives/2003/july03/index.html (last visited July 4, 2006); Barry James, International Education/A Special Report: France Pushes Decentralization, INTERNATIONAL HeRALD TRIBUNE, Feb. 18, 2003, available at http://www.iht.com/ articles/2003/02/18/rfrance_ed3_php (last visited July 4, 2006).

18 Woodrow Wilson, The Study of Administration, 2 PoL. SCl. Q. 197, 209-210 (1887).

${ }^{19}$ In a Labor Day Speech, while campaigning in New York, Wilson exhorted:

What I fear, therefore, is a government of experts. God forbid that in a democratic country we should resign the task and give the government over to experts. What are we for if we are to be [scientifically] taken care of by a small number of gentlemen who are the only men who understand the job? Because if we don't understand the job, then we are not a free people. We ought to resign our free institutions and go to school to somebody and find out what it is we are about.

W. Wilson, A Crossroads of Freedom: The 1912 Campaign Speeches of Woodrow Wilson 83 (J. Davidson ed., 1956). 
This belief in administration as a science and expertise as the saving grace of governance flourished well into the New Deal. ${ }^{20}$ According to this perspective, when government perceives a problem it appoints a commission or agency to regulate or manage the problem. The entire field, so to speak, should be left to the agency's expert judgment of how, when, and in what way to fill in the regulatory canvass. This perspective has been carried on by jurists like Justice Stevens with his penchant that "broad discretion" be afforded agencies to "meet new and unanticipated problems."21 We should note, however, that Stevens wrote in dissent, and that the staying power of such regulatory maximalism is clearly contested within the Court and the legislature.

This undercurrent of American history is dwarfed by a fundamental continuum of American political thought-Americans distrust bureaucracy. ${ }^{22}$ This "deep uneasiness," as James Freedman has put it, "about the coercive and dehumanizing influence of bureaucratic organizations ${ }^{\prime 23}$ has a number of sources. One reason is the belief that bureaucracies "too often appear concerned primarily with formalistic adherence to their own rules, rather than with seeking a personalized response to the peculiarities of [the individual's] specific circumstances." ${ }^{24}$ This concern that the letter of the law often undercuts its "spirit" is well described in Philip Howard's best seller, The Death of Common Sense. 25

Howard argues that while "we don't trust bureaucrats," giving them discretion is "the only way for them to do anything, and the only way for us to know who to blame." ${ }^{26}$ Thus, he wants to give bureaucrats flexibility to waive rules or not to waive rules, to accept individuated compliance solutions; in short, to ignore the letter of the law to accomplish its "spirit." 27 Ironically, Howard's remedy for pervasive over- and under- inclusiveness in regulatory enforcement is to empower bureaucrats by giving them even more responsibility (or in administrative law terms more discretion) to take

\footnotetext{
${ }^{20}$ See James M. Landis, The Administrative Process 23-26 (1938), depicting the evolution of the need for technologically competent regulatory agencies for the "translation of [New Deal economic] legislation into reality."

${ }^{21}$ MCI v. AT\&T, 512 U.S. 218, 235 (1994)(Stevens, J. dissenting); see also STEPHEN BREYER, ACTIVE LIBERTY 102-03 (2005).

${ }^{22}$ Richard H. Pildes \& Cass R. Sunstein, Reinventing the Regulatory State, 62 U. CHI. L. Rev. 1, 40-42 (1995).

${ }^{23}$ James O. Freedman, Crisis and Legitimacy in the Administrative Process, 27 StAN. L. REV. 1041, 1068 (1975).

${ }^{24} \mathrm{Id}$. at 1066.

${ }^{25}$ Philip K. Howard, The Death of Common Sense: How Law is Suffocating Ameruca (1994).

${ }^{26} \mathrm{Id}$. at $180-81$.

${ }^{27} \mathrm{Id}$.
} 
matters into their own hands. ${ }^{28}$ As Howard explains, "if there is no flexibility for the regulator, there is no flexibility for us." 29

A second strand of distrust of bureaucracy is reflected by critics like former Congressmen Newt Gingrich or Tom Delay who believe that "[r]egulatory agencies have nu amuck and need to be reformed," 30 and that laissez-faire or market-based solutions are presumptively superior to regulatory regimes. While they want fewer regulations, they also want to place substantial burdens on the regulatory process itself. Thus, they seek to restrict the flexibility and discretion of administrative agencies through procedural constraints. ${ }^{31}$ As Howard incisively points out, "[o]ne of the worst elements of the Republicans' plan for regulatory reform is that they want to make it even harder to pass a new rule" 32 Indeed many would prefer "clogging the wheels of the federal bureaucracy," 33 taking ironic pride in "add[ing] more red tape and judicial oversight," 34 if not admitting that such action is a "recipe for paralysis." 35 For, as former Congressman David McIntosh suggests, "many Americans think paralyzing the federal government would be a good thing." ${ }^{, 36}$

Some have argued that we are now at a kind of "constitutional moment," to borrow from Bruce Ackerman, ${ }^{37}$ where American politics defaults to market-based solutions

${ }^{28} I d$. at 180 .

${ }^{29}$ Id. at $180-81$.

${ }^{30}$ Edmund L. Andrews, A Rising Deregulation Wave: Republicans Advance Pro-Business Agenda, Int'l Herald Trib., Jan. 3, 1996, at 12; see also Rep. Tom DeLay, DeLay Seeks His "Holy Grail": Regulatory Reform, Roll CALL, Dec. 4, 1995, at 15.

${ }^{31}$ See generally Loren A. Smith, Judicialization: The Twilight of Administrative Law, 1985 DuKE L.J. 427, 430, 437-38 (1985).

32 Regulatory Reform: The Case for Common Sense, An Interview with Philip K. Howard, THE WASH. MONTHLY, Sept. 1995, at 23, 26 (quoting Mr. Howard during an interview concerning his book, THE Death of Common Sense).

${ }^{33}$ Robert W. Hahn, Regulatory Reform - The Whole Story, WaLL St. J., Feb. 27, 1995, at A12 (arguing that current congressional regulatory reform efforts may be largely symbolic and that effective reform will require more substantive changes in the law).

${ }^{34}$ Id.

${ }^{35}$ Id.; The Next Environmental Threat, N.Y. TIMES, Feb. 12, 1995, s4, at 14.

${ }^{36}$ See Hearings on the Regulatory Transaction Act of 1995, H.R. 450 Before the Subcomm. On National Economic Growth, Natural Resources and Regulatory Affairs, Comm. On Government Reform \& Oversight, 104 ${ }^{\text {th }}$ Cong., $1^{\text {st }}$ Sess. (Jan. 19, 1995)(opening statement of Congressman David McIntosh stating that "unnecessary regulation has hurt the American people" and calling for a six month moratorium on new federal regulations).

${ }^{37}$ Bruce Ackerman, We the People: Foundations 49-50, 107-08 nn.4-5 (1991); 2 Bruce Ackermax;, We the People: Transformations 311 (1998); BruceAckerman, Constitutional Politics/Constitutional Law, 99 Y ALE L.J. 453, 457-61, 510-15 (1989). For a critique, see Michael J. Klarman, Constitutional Fact/ Constitutional Fiction: A Critique of Bruce Ackerman's Theory of Constitutional Moments, 44 StAN. L. Rev. 759, 766-75 (1992). 
and where the proponents of regulation have, as it were, the burden both of production and of proof. ${ }^{38}$

A third source of American skepticism of federal bureaucracy comes from our belief in subsidiarity, or in our constitutional terminology, federalism. The French view that every classroom in the country should have the same teaching schedule has historically not set well with Americans. Some areas are constitutionally left to the states to regulate, and thus federal bureaucracy is structurally limited as to its range of activity.

Some commentators (usually academics) have proposed new approaches to government intervention based on informal approaches to regulatory management. These initiatives, variously termed "democratic experimentalism," 39 cooperative regulation, ${ }^{40}$ and "the Renew Deal,"41 are all premised in the view that "Americans still want government to tackle... [large problems]; they just don't want government to tackle these problems via the characteristic institutional form of the New Deal-Great Society constitutional order, namely, bureaucracy."42 Thus they use techniques such as "contracting out," "public-private partnership," 44 and "reflexive" or "individuated"

${ }^{38}$ Cass Sunstein distinguishes two strands of regulatory reform in the $1990 \mathrm{~s}$, a technocratic and a reactionary strand. Cass Sunstein, Legislative Foreword: Congress, Constitutional Moments and the Cost-Benefit State, 48 StaN. L. REv. 247, 270-271 (1998). The technocratic approach proposes "rationality" techniques to improve the regulatory process. The goal of the reactionary approach "was to stall or eliminate regulation whatever its content-largely with procedural requirements so extensive as to prevent agencies from doing much at all." Id. at 271.

${ }^{39}$ Michael C. Dorf \& Charles F. Sabel, A Constitution of Democratic Experimentalism, 98 CoLuM. L. REV. 267 (1998)(proposes to permit industry adoption of best practices in exchange for freedom to experiment with alternative regulatory possibilities.)

${ }^{40}$ The term originated in the field of securities regulation. In the 1930s, Congress mandated "industry self-regulation through the creation of registered national securities associations... [with the intent of establishing] ... a 'cooperative regulation' ... [regime by which such] associations would regulate [their numbers] under the supervision of the SEC." Jones v. SEC, 115 F.3d 1173, 1179 (4th Cir. 1997)(quoting S. Rep. No. 75-1455, at 3-4; H.R. Rep. No. 75-2307, at 4-5). More recent examples include OSHA's VPP program see U.S. Department of Labor, Occupational Health \& Safety Administration, Voluntary Protection Programs, available at http://www.osha.gov/dcsp/vpp/index. html (last visited November 2, 2006); and EPA's Project XL. See U.S. Environmental Protection Agency, Project XL, http://epa.gov/projectxl/file2.htm (last visited November 2, 2006).

${ }^{41}$ Orly Lobel, The Renew Deal: The Fall of Regulation and the Rise of Governance in Contemporary Legal Thought, 89 MinN. L. Rev. 342, 352-56 (2004).

${ }^{42}$ Michael Dorf, After Bureaucracy, 71 U.C.L.A. L. Rev. 1245, 1271 (2004).

${ }^{43}$ For a discussion regarding privatization by means of government contracting, see Jody Freeman, The Contracting State, 28 FLA. ST. U.L. REv. 155, 169 (2000), who urges that, through contracting, many government agencies rely on "a private work force to assist them in implementing laws and regulations," including the provision of services and execution of daily functions.

44 The use of public-private partnerships to tackle significant problems can be found in nearly every area of administrative law. See, e.g., Nathaniel Lipkus, How to Understand Product Development: 
regulation $^{45}$ all of which attenuate the federal bureaucracy's involvement in the regulatory process.

While democratic deficits have been noted in other jurisdictions (including the EU Commission), ${ }^{46}$ the deficit has been overcome by appeal to a technocratic paradigm, i.e., the experts know best. Not so in the US, where American distrust of bureaucracy creates what is the central goal of American administrative law: a "normative yearning," in Peter Lindseth's words "for democratic legitimacy."47 Put simply, administrative law and the actions of administrative agencies are not instinctively legitimate - as the administrators do not obviously reflect the will of the people and the administrators in the modern administrative state are given significant discretion. This raises the question of whether the nature of administrative decision-making is not consonant with a "rule of law" regime. ${ }^{48}$ As I suggested above, this is not a problem in France and in numerous other legal jurisdictions. This kind of difference in political and social philosophy challenges the view that administrative law worldwide has a common evolving structure, a view reflected perhaps in the efforts of academics at

Public-Private Partnerships as Vehicles for Innovation in Combating Neglected Disease, 10 Mich. ST. J. MED. \& LAW 385 (2006)(discussing the use of public-private partnerships in drug and vaccine development); Haley Stein, Intellectual Property and Genetically Modified Seeds: The United States, Trade, and the Developing World, 3 Nw. J. TECH. \& INTELL. Prop. 160, 174-78 (2005)(addressing the potential for public-private partnerships to "balance the need for strong IP protections for business while maintaining developing world access to genetically modified seeds."); Cheryl L. Wade, Lessons From A Prophet on Vocational Identity-Profit or Philanthropy?, 50 ALA. L. Rev. 115 (1998)(examining the use of public-private partnerships in the management of public schools).

${ }^{45}$ Eric W. Orts, Reflexive Environmental Law, 89 N.W. U. L. REv. 1227, 1232 (1995). For example, reflexive regulation in the environmental law context means "[w]ith engendering a practice of environmentally responsible management" where businesses impose upon themselves policies which "minimize environmental harms and maximize benefits."). See also Richard B. Stewart, $A$ New Generation of Environmental Regulation?, 29 CAP. U. L. REV. 21, 130-34 (2001).

${ }^{46}$ Michel Rosenfeld, Comparing Constitutional Review by the European Court of Justice and the U.S. Supreme Court, 4 INT'L J. Const. L. 618, 631-32 (2006); Theodora Kostakopoulou, Democracy Talk in the European Union: The Need for a Reflexive Approach, 9 Colum. J. EuR. L. 411, 41112 (2003)(arguing "that the question of democracy in the European Union cannot be addressed adequately without first addressing the suitability of existing models of national democracy for the formation of the European polity, and perhaps without radically transforming these models.").

${ }^{47}$ Peter Lindseth, Democratic Legitimacy and the Administrative Character of Supranationalism: The Example of the European Community, 99 CoL. L. REv. 628, 694 (1999).

${ }^{48}$ Richard B. Stewart, The Reformation of American Administrative Law, 88 HARv. L. Rev. 1669, 1672 (1975)(noting that, "With the possible exceptions of military and foreign affairs functions and times of national emergency, the Constitution recognizes no inherent administrative powers over persons and property."). See id. at 1676 ("Vague, general, or ambiguous statutes create discretion and threaten the legitimacy of agency action."). 
NYU law school to discern (I would say create) a "single global administrative space" in international law. ${ }^{49}$

\section{Attempts to Meet the Challenge of the Quest for Legitimacy}

This quest for legitimacy has led theorists of American administrative law to undertake four interrelated projects. I will call them the Accountability Project, the Rationality Project, the Transparency Project, and the Participatory Project. Each is an effort to address the problem of democratic legitimacy by appealing to a kind of faux legitimacy—one which reflects a rough substitute for the democratic process.

As the limits of one project becomes clear, another comes to the fore. At any one moment in time, therefore, administrative law may contain all these efforts. As Gerald Frug has noted (in regard to a comparable classification), "each model has not simply replaced its predecessor. Instead, each has been added to the others, so that in the end all of them have become part of legal discourse"; 50 yet none fully succeed, nor can they. For the price one pays for rejecting the technological paradigm is that you must rely on a "populist" or democratic paradigm to secure legitimacy in the administrative state. But when you talk about democratic legitimacy and the administrative state, you talk about a circle that cannot easily be squared.

${ }^{49}$ This "single global administrative space" is said to be distinct from the traditional domains of international law and domestic administrative law, and is increasingly govemed by an emerging "global administrative law" (GAL), which regulates decision-making and rule-making processes in global regulatory administrative systems. See Benedict Kingsbury, Nico Krisch \& Richard B. Stewart, The Emergence of Global Administrative Law, 68 LAW \& CONTEMP. ProBs. 15 (2005) available at http://www.law.duke.edu/journals/lcp/ (last visited July 9, 2006). A skeptical "take" on the conceptual underpinnings of the politics and sociology of this project can be found in Kenneth Anderson \& David Rieff, Global Civil Society: A Skeptical View, in Global Civil SocIeTY 2004/5 26 (2005).

${ }^{50}$ Gerald E. Frug, The Ideology of Bureaucracy in American Law, 97 HARv. L. REv. 1277, 1284 (1984).

Lisa S. Bressman, Beyond Accountability: Arbitrariness and Legitimacy in the Administrative State, 78 N.Y.U. L. REv. 461, 469 (2003)[hereinafter Bressman, Beyond Accountability](citing Elena Kagan, Presidential Administration, 114 HARv. L. Rev. 2245, 2253-54 (2001)), asserts that the various models of the administrative state "did not so much succeed each other as "bleed into each other." Kagan cites Frug for the premise that the models for mechanisms to approximate democratic legitimacy intermingled chronologically. Id. Bressman goes further, imposing this concept on the models themselves. I do not accept this last formulation, but rather suggest that the models co-exist, independently, within the "legal discourse." See Bressman, Beyond Accountability at 469 . 
The Accountability Project reflects the effort of the Anglo-American common law since the Middle Ages to constrain executive authority undertaken beyond the limits of the law. Its principles were developed in the famous $17^{\text {th }}$ century litigation, styled Dr. Bonham's Case, ${ }^{51}$ which discussed judicial review of executive decisions.

The Rationality Project emerged after World War II and attempted to constrain the administrative state by requiring that it act in a rational manner. The reality that, in the modern world, more and more power was being delegated to administrative agencies raises obvious problems in democratic accountability. One way to make up for the accountability deficit was to demand that the courts protect the rationality of agency decision-making. To put it otherwise, if we are not able to provide democratic accountability through the electoral process, we can create virtual accountability by demanding rationality (the presumption perhaps being that the popular will and the rational thing to do will be in some measure congruent).

The Transparency Project is a post World War II approach that uses transparency -openness in government - as another method of ensuring legitimacy. Transparency is seen as a substitute for accountability. The theory is that if the public is aware of government actions, as well as the reasons for and background behind those actions, the government will be likely to make certain its actions are more closely in accord with the public will. Thus it is thought that transparency would provide a methodology that provides virtual democratic legitimacy.

The Participatory Project was an effort to increase public participation in the administrative rulemaking process. It was believed that such participation would increase the legitimacy of the rulemaking process by serving a functional substitute for the fact that bureaucrats are not properly elected.

\section{A. The Accountability Project}

The historic project of the English common law judges was to claim jurisdiction over executive action and to regulate when the executive acted outside the powers given

st 8 Co. Rep. 107a, 113 b, 77 Eng. Rep. 638, 646 (C.P. 1610). For a detailed examination of the case, analyzing Bonham in terms of English constitutional theory (rather than statutory construction), see Raoul Berger, Dr. Bonham 's case: Statutory Construction or Constitutional Theory?, 117 U. PA. L. REv. 521 (1969). A recent appreciation of Bonham as it came to be understood in the United States can be found in Larry D. Kramer, The People Themselves-Popular Constitl monalism AND JudiCIAL REVIEW 19-24 (2004). 
to it by law. This was the essential purpose of the five prerogatory common law writs: mandamus, probation, certiorari, quo warranto and the great writ of habeas corpus. By thus keeping the executive within the bounds set by the legislature, the accountability paradigm attempts to offer a substitute for democratic legitimacy. ${ }^{52}$

In contrast, "the French thought of judicial review as violating the separation of powers." 53 Indeed, the French revolutionary decree of August 16 and 24, 1790 prohibited judicial review of administrative action, noting that "[j] udicial functions are distinct and will always remain separate from administrative functions. Judges may not, under pain of forfeiture of their offices, concern themselves in any manner whatsoever with the operation of the administration, nor shall they summon administrators to appear before them on account of their official functions." 54 To appeal improper administrative action, French citizens had to appeal to specialized tribunals that were themselves part of the executive branch. ${ }^{55}$

Sometimes the question of whether the executive acted beyond the powers afforded him by statute is easy. The statute says do X; the executive should be ordered to do $\mathrm{X}$.

However, this is true only when $\mathrm{X}$ is a simple ministerial act, e.g., when the river reaches 10 feet high on a flood marker, open the sluice gates to relieve the pressure on the dam. Here, there is very little discretion involved in the ascertainment of whether the river is $10 \mathrm{ft}$ high. The act is ministerial. If the executive fails to follow that statutory directive he can be ordered to do so by a court under a writ of mandamus.

\footnotetext{
${ }^{52}$ The matter is best put in Dr. Bonham's case, decided in 1610, supra note 51 In that case, an Act of Parliament during the reign of King Henry VIII had established a medical licensing board, a "college perpetual of physicians and grave men." Id. at 107b. Bonham had persisted in a medical practice unlicensed by the board. For this unlicensed practice, he was imprisoned for seven days for contempt of the board. Consequently, Bonham brought an action for false imprisonment against the board members. By that tort action, he sought to gain judicial review of the propriety of the board's action against him.

The Court of Common Pleas took the case. In his opinion for the court, Lord Coke found that the licensing board's determination that Bonham was "insufficient and inexpert in the art of medicine" was reviewable. $I d$. at $110 \mathrm{~b}$. Explaining that "they [the board] are not made judges nor a court given them ...." See id. at 118a. Coke wrote that review by a court was essential if Dr. Bonham was to have an "adequate remedy." See id. at 119a.

${ }^{53}$ Gerhard Casper, Separating Power: Essays on the Founding Period 151 (1997).

${ }^{54}$ Id. at 135 (1997)(citing Decree of August 16-24, 1790, title II, art. 13, 363).

55 L. Neville Brown \& John S. Bell, French Administrative Law 47 (5th ed. 1998).
} 
The real world is rarely so simple. Much depends on whether you understand executive action to be ministerial or a matter of discretion. And if it is a matter of discretion, does this mean that the executive can do whatever it wants, e.g. open the sluice at two feet, twelve feet, or wait until twenty feet?

We should note that American courts in the $19^{\text {th }}$ century took a very restricted view of the kinds of actions that were reviewable. ${ }^{56}$ Before the Civil War, the Supreme Court utilized what one might call a res judicata model of judicial review, "reallocat[ing] much final decisional authority to the executive branch" and focusing "on the jurisdiction" of the executive to act. ${ }^{57}$ Also, the kind of executive branch action that was reviewable was limited to ministerial acts and not discretionary acts. Furthermore, the concept of a discretionary act was extremely broad.

Take the famous 1840 case of Decatur $v$. Paulding. ${ }^{58}$ In that case, the widow of the $19^{\text {th }}$ Century naval hero, Stephen Decatur, sought a writ of mandamus to compel the Secretary of the Navy to pay her two pensions - one under a general pension law and the other under a special act of Congress passed for her alone. The Court held that the Secretary's decision not to pay the second pension was "discretionary," not "ministerial," because he had to decide (1) whether to reverse a predecessor's decision on the subject, (2) how half-pay should be calculated, and (3) whether there was enough money in the pension fund to satisfy all claims. The Court's attitude is well expressed in its statement that the "interference of the Courts with the performance of the ordinary duties of the executive departments of the government, would be productive of nothing but mischief; and we are quite satisfied that such a power was never intended to be given to them." 59 Thus the principles of Decatur left little range for judicial review as it made almost all executive conduct "discretionary."

Even up until 1900, the Court held that "courts have no general supervising power over the proceedings and action of the various administrative departments of the government." 60 However, institutional changes were afoot that would soon affect

${ }^{56}$ Frederic P. Lee, The Origins of Judicial Control of Federal Executive Action, 36 Geo. L.J. 287, 295 (1948).

57 Ann Woodhandler, Judicial Deference to Administrative Action-A Revisionist History, 43 ADMIN. L. Rev. 197, 244 (1991).

${ }^{58}$ Decatur v. Paulding, 39 N.Y.U. L. (14 Pet.) 497 (1840).

${ }^{59}$ Id. at 516. See also Martin v. Molt, 25 U.S. (12 Wheat.) 19, 32-33 (1827)(stating that statutes conferring discretionary power make the recipient the sole judge of the facts on which such discretion should be exercised).

${ }^{60}$ Keim v. United States, 177 U.S. 290, 292 (1900)(holding that the removal of a clerk by the Secretary of the Department of the Interior for inefficiency is not reviewable). 
legal doctrine. In the second half of the $19^{\text {th }}$ Century, the national government faced the challenge of regulating economic monopolies, or oligopolies-in particular the railroads, which were "a central, if not the major, element in the political, economic, and social development of the United States." 61 The administrative commission form of regulation had earlier been employed in Britain ${ }^{62}$ and at the state level in the United States. ${ }^{63}$ The statutory creation of the Interstate Commerce Commission in 1887 was the natural derivation of these experiments. With the advent of national regulation, the courts began to examine the powers of administrative entities, ${ }^{64}$ although the presumption of unreviewability was not reversed until the Supreme Court's 1902 decision in American School of Magnetic Healing v. McAnnulty. ${ }^{65}$ In that case, the Supreme Court found that the presumption was not applicable even though Congress had not spoken to the question of judicial review. The Court stated that where an official makes a mistake of law and acts outside the limits of his authority, "the courts... must have power in a proper proceeding to grant relief. Otherwise, the individual is left to the absolutely uncontrolled and arbitrary action of a public and administrative officer, whose action is unauthorized by any law and is in violation of the rights of the individual."

Since Magnetic Healing, we live in a world that presumes judicial review of administrative action. In large measure, that is because the discipline judicial

${ }^{61}$ Gabriel Kolko, Railroads and Regulation $1877-19161$ (1st ed. 1965).

${ }^{62}$ In discussing regulation in Britain, I have relied on three principal sources suggested to me by Gary Edles at the University of Hull. The first is a book by historian Henry Parris, GoverNMENT AND the Railways IN NinEteenth-CentuRy Britain (1965). The book is a revised version of Dr. Parris's Ph.D. thesis at the University of Leicester. At the time of writing, he was a Lecturer in Politics at the University of Durham. The second is a book by economist C.D. Foster. C.D. Foster, Privatization, Public Ownership, and the Regulation of Natural Monopoly 44-52 (1992). Sir Christopher Foster held a chair at the London School of Economics, was a British civil servant, and is a senior partner of Coopers and Lybrand. At the time of writing during John Major's Administration, he was special advisor to the U.K. Secretary of State for Transport on railway privatization. The third source is an 1886 report by the Senate Committee on Interstate Commerce that preceded passage of the Act to Regulate Commerce of 1887 . S. Rep. No 49-46, pt. 1, 54-63 (1886).

${ }^{63} I d$. at 65-66.

${ }^{64}$ See, e.g., Interstate Commerce Commission v. Cincinnati, New Orleans and Tex. Pac. Ry. Co., 167 U.S. 479 (1897)(concluding that the ICC's statutory power to determine the reasonableness of rates did not include the power to prescribe rates, and discussing different forms of regulation, by the various states, that pre-dated the creation of the ICC).

${ }_{65}$ Am. Sch. of Magnetic Healing v. McAnnulty, 187 U.S. 94 (1902). A presumption of judicial reviewability of agency action was expressly established in Abbott Laboratories v. Gardner, 387 U.S. 136 (1967).

${ }^{66}$ Magnetic Healing v. McAnnulty, supra note 65, at 110. 
accountability offers a way to overcome administrative law's democratic deficit. ${ }^{67}$ Thus, the central theoretical issue for administrative law in the 20th century has been the drive to curtail agency discretion both through formalized adjudication procedures and judicial review. This fear of empowering bureaucrats with flexibility refiects a traditional concern that the administrative state, if unchecked, would likely act arbitrarily and capriciously. ${ }^{68}$

The so-called "bible" of administrative procedure-the 1946 Administrative Procedure Act or APA ${ }^{69}$ - tells us that courts should preclude judicial review only where specifically precluded by statute or when an action is committed to agency discretion by law and therefore is an action not amenable to review. ${ }^{70}$ Courts also read statutes that preclude judicial review exceedingly narrowly. ${ }^{71}$ Thus, when a statute said that senior citizens cannot appeal a medical benefit determination, courts have determined that the ban may apply to individual benefits but not to an attack on the methodology used to determine awards. ${ }^{72}$ And similarly, when a statute did not allow for judicial review of veterans' educational benefits, courts have found that the preclusion does not apply to a constitutional claim regarding that benefit system before a federal court. ${ }^{73}$

The Supreme Court has even taught that it would be unconstitutional to preclude judicial review of a constitutional claim. In a highly unusual case concerning the hiring practices of the Central Intelligence Agency, the Court struggled with the question of whether there were situations in which constitutional claims can be forbidden judicial

${ }^{67}$ Lisa Bressman, Judicial Review of Agency Inaction: An Arbitrariness Approach, 79 N.Y.U. L. REv. 1657, 1658-59 (2004) [hereinafter Bressman, Judicial Review], argues that it is "erroneous" to believe that "the constitutional structure is committed foremost to promoting political accountability." I disagree. While there are certainly other important principles supported by our constitutional structure, democratic legitimacy is historically and necessarily the primary area of concern.

${ }^{68}$ Marshall J. Breger, Government Accountability in the Twenty-First Century, 57 U. PrTT. L. REV. 423, 434 (1996). See also the classic American study on the structuring of discretion K.C. DAvIs, DISCRETIONARY JUSTICE: A PRELIMINARY INQUIRY 55-68, 111, 226-27 (1969), urging different methods of structuring discretionary power, particularly more extensive use of rule making and increased openness in informal processes, in order to combat arbitrariness.

69 5 U.S.C. $\$ \S 551,553-59,701-06(2000)$.

70 5 U.S.C. $\S 701$ (a) $(2000)$.

${ }^{7}$ Consider, as example, Zadvydas v. David, 533 U.S. 678 (2001), where the Supreme Court found that statutory measures enacted to limit a deportable alien's right to habeas corpus could not apply in the absence of a specific statute applying to a post-removal-period detention.

${ }^{72}$ Bowen v. Michigan Academy of Family Physicians, 476 U.S. 667, 678 (1986).

${ }^{73}$ Johnson v. Robison, 415 U.S. 361 (1974). 
review. ${ }^{74}$ The majority found that even in the case of an intelligence agency the idea of judicial review of the constitutional claims cannot be denied. ${ }^{75}$ I should point out that Justice O'Connor strongly argued in her dissent that if it were possible to preclude judicial review of administrative decisions when there is a constitutional claim anywhere, this might be the case. ${ }^{76}$ And Justice Scalia dissented, arguing that there is no right to judicial review of every constitutional claim of due process. ${ }^{77}$

Even when Congress decided that visa revocation decisions are insulated from judicial review ${ }^{78}$ federal courts, consistent with the "strong presumption for judicial review," have managed to carve out a place for themselves. They have done so by either narrowly interpreting statutory grants of discretion, ${ }^{79}$ or by determining that provisions of the Immigration Act provided the Attorney General with objective legal criteria to use in his decision and thus did not give him unfettered discretion. ${ }^{80}$ This

${ }^{74}$ Webster v. Doe, 486 U.S. 592 (1988), concerned a man discharged from the CIA after he voluntarily revealed that he was a homosexual, since the agency viewed his sexual preference as a security risk. Since the Director of the CIA had statutory authority to protect intelligence sources and methods from unauthorized disclosure, Doe's discharge depended on the subjective judgment of the director and there was no law to apply. In contrast, the recent case of Tenet v. Doe, $125 \mathrm{~S}$. St. 1230 (2005), concerns two former spies for the United States, no United States citizens, who sued the federal government to enforce its promise to "take care of them" once they came to the United States. The Court found that the United States was insulated from suits based on covert espionage agreements. See also Totten v. United States, 92 U.S. 105 (1876).

${ }^{75}$ Webster $v$. Doe, supra note 74, at 603.

${ }^{76} I d$. at 605 (O'Connor, J., concurring in part and dissenting in part).

77 Id. at 613-14.

${ }^{78}$ See Illegal Immigration Reform and Immigrant Responsibility Act, Pub. L. 104-208, 110 Stat. 3009-546 (1996). It should be noted that Court has recognized Congress's ability to cut of judicial review entirely in other areas as well. See Johnson v. Robinson, 415 U.S. 361 (1974)(precluding judicial review of certain Veteran's Administration determinations); Morris v. Gressette, 432 U.S. 491 (1997)(finding that the Attorney General's failure to make a timely objection under the Voting Rights Act of 1965 is not subject to judicial review); Block v. Community Nutrition Institute, 467 U.S. 340 (1984)(consumers of dairy products could not obtain judicial review of milk market orders); Webster v. Doe, supra note 74, (holding CIA director's decision to discharge an employee was not subject to judicial review).

79 Such that review of Immigration Judge's continuances were found not to be "mentioned specifically" as committed to agency discretion. See Khan v. Att'y Gen., 2006 U.S. App. LEXIS 12524 (3d Cir. 2006), Sanusi v. Gonzales, 445 F.3d 193 (2d Cir. 2006), Zhao v. Gonzales, 404 F.3d 295 (5th Cir. 2005), Zafar v. Att'y Gen., 426 F.3d 1330 (11th Cir. 2005), Medina-Morales v. Ashcroft, 371 F.3d 520 (9th Cir. 2004), Soltane v. U.S. Dep't of Justice, 381 F.3d 143 (3d Cir. 2004), and Spencer Enters., 345 F.3d 683 (9th Cir. 2003)(narrowly interpreting the bar to judicial review created by 8 U.S.C. $\S 1252(\mathrm{a})(2)(B)(i i)(2000))$. But see Yerovich v. Ashcroft, 381 F.3d 990 (10th Cir. 2004), and Samirah v. O'Connell, 335 F.3d 545 (7th Cir. 2003)(interpreting broadly the bar to judicial review created by 8 U.S.C. $\S 1252(\mathrm{a})(2)(B)(\mathrm{ii})(2000)$ ).

${ }^{80}$ See ANA Int'l Inc. v. Way, 393 F.3d 886 (9th Cir. 2004)(interpreting 8 U.S.C. $§ 1155$ as "not entirely discretionary.") But see Jilin Pharmaceuticals USA Inc. v. Chertoff, 2006 U.S. App. LEXIS 11589 (3d Cir. 2006)(interpreting 8 U.S.C. $\S 1155$ as entirely discretionary). 
means that there is, in the APA's language, "law to apply" and that "the right or power to act is plainly not entirely within the Attorney General's judgment or conscience."81

An interesting variant on this is the question of whether ongoing nonfeasance can be reviewed. ${ }^{82}$ In the 1980 's, the Court in Heckler $v$. Chaney ${ }^{83}$ found that an agency decision refusing to regulate drugs used for lethal injections in executions was not reviewable. The Court referenced the long common law tradition of prosecutional discretion, the agency's need to make resource allocation decisions and the lack of any legal standards (or "law") to apply. It held that the failure to regulate in a specific area was not an agency action appropriate for judicial review. ${ }^{84}$ Broadening Heckler, in Norton v. Southern Utah Wilderness Alliance ${ }^{85}$ the Supreme Court determined that an allegation that the Bureau of Land Management's (BLM) failed to manage wilderness lands according to requirements of the Federal Land Policy Management Act of 1976 is not subject to judicial review because the BLM was given by statute a great deal of discretion in deciding how to implement its mandate.

The court found that the kind of agency action (or failure to act) properly reviewable under the APA was "properly understood to be limited... to a discrete action." And the Court made clear that " $\mathrm{t}]$ he prospect of pervasive oversight by federal courts over the manner and pace of agency compliance with such congressional directives is not contemplated by the APA." 87

Some commentators have suggested that the Norton court's "analysis cuts against the logic of modern administrative law," ${ }^{, 88}$ specifically the broad presumption of judicial

${ }^{81}$ ANA, 393 F.3d at 894.

${ }^{82}$ It is noteworthy that the Court has granted certiorari to consider the issue of nonfeasance in the context of an EPA decision not to regulate carbon dioxide and three other "greenhouse gases." Massachusetts v. EPA, 415 F.3d 50, 56-57 (D.C. Cir. 2005), cert. granted, 126 S. Ct. 2960 (2006).

${ }^{83}$ Heckler v. Chaney, 470 U.S. 821 (1995).

${ }^{84}$ A similar position was taken in United States v. Bean, 537 U.S. 71 (2002), where the Bureau of Alcohol, Tobacco, and Firearms (ATF) refused to act on an individual's request to be relieved of a statutory bar on firearms ownership by felons. ATF had returned Bean's petition without acting on it because Congress had prohibited expenditure of any funds for processing such applications. A unanimous Court held that judicial review was unavailable under either the specific statute or the APA in the absence of an actual decision on the application.

${ }^{85}$ Norton v. S. Utah Wilderness Alliance, 542 U.S. 55 (2004).

${ }^{86} I d$. at 63.

${ }^{87} \mathrm{Id}$. at 67.

${ }^{88}$ William D. Araiza, Administrative Law Discussion Forum: In Praise of a Skeletal APA: Norton $v$. Utah Southern Wilderness Alliance, Judicial Remedies for Agency Inaction, and the Questionable Value of Amending the APA, 56 ADMIN. L. REv. 979, 983 (2004). 
review. Whether that presumption has reached its apogee remains to be seen. Indeed, it may well be that increased executive control of the agency rulemaking process and more vigorous congressional oversight (discussed below) may be replacing, in part, the accountability function of judicial review. But to the extent to which we have reached the limits of the accountability project through the courts, I believe it is because the courts cannot themselves solve the legitimacy problem.

I should make clear that the presumption of review has no analytical connection to the question of standing. While there can be no doubt that the Supreme Court, starting in the 1960's, relaxed standing requirements with the result of increasing access to courts, the Court has clearly begun to "right" itself, recognizing that there are both constitutional limitations in standing as well as prudential concerns limiting who can sue. The Constitution's Article III constraint constitutes a requirement that there actually be a case or controversy, thus requiring that the plaintiff have a concrete injury. ${ }^{89}$ The Constitution's Article II concerns make clear that decisions whether or not to enforce statutes is an executive function not a private sector decision. ${ }^{90}$

\section{B. The Rationality Project}

Another important feature of American administrative law is its focus on rationality as a justification for agency action. Indeed, as Jerry Mashaw suggests, reason is "an exclusive ground for legitimacy" in administrative law. ${ }^{91}$ And the "force of reason"92 matters in administrative law specifically because the administrative process lacks the legitimacy of the legislative process. Over a quarter of a century ago, in National

${ }^{89}$ U.S. Const. art. III, $\S 2$, cl. 2.

${ }_{90}$ These views, of course, differ markedly from the Israeli position which has apparently expanded to a kind of non-Hohfeldian citizens standing, largely eviscerating the concept as an analytical tool. Thus, the Israeli High Court in Ressler v. the Minister of Defense determined that any claim related to government misconduct can be heard directly, through the bagatz procedure, in the Israeli High Court. See HCJ 910/86 Ressler v. the Minister of Defense [1988] 42(2) P.D. 441. See also HCJ 217/80 Segal v. the Minister of Interior [1980] 34(4) P.D. 429, 443 (acknowledging the standing of public petitioners in environmental cases); HCJ 1/81 Shiran v. Israeli Broadcasting Authority [1981] 35 P.D. 365 (acknowledging that emotional injury may be a basis for standing).

This elastic, indeed some might say, promiscuous, approach to standing does more than promote government accountability to a "rule of law" regime, it substitutes the courts for the executive in implementing legal rules.

91 Jerry L. Mashaw, Small Things Like Reasons are Put in a Jar: Reason and Legitimacy in the Administrative State, 70 FordHAM L. REv. 17, 20 (2001).

${ }_{92}$ Id. 
Tire Dealers \& Retreaders Assn., Judge Malcolm Wilkey of the DC Circuit struck down portions of a Highway Safety Administration standard that were not backed up by adequate rational justification. However, those portions of the standard mandated by Congress were upheld, notwithstanding a lack of adequate justification. As Judge Wilkey opined, "No administrative procedure test applies to an act of Congress." 93 This emphasis on rationality is underscored by the judicial articulation of the notice and comment requirement for APA informal rulemaking ${ }^{94}$ and in the various White House mandates for cost benefit studies prior to issuing "major" regulations. ${ }^{95}$ As Peter Strauss has underscored:

[r]equirements of rulemaking "rationality" thus serve to impose practical bounds on agency judgment that do not exist for legislatures; Congress can with impunity amend a statute in selfcontradictory ways, but an agency trying to "have it both ways" will likely fail the judicial test of rationality. From a perspective that puts a high value on the place of reason in even political discourse among citizens, this virtue might be thought to counterbalance the missing discipline of the ballot box. ${ }^{96}$

The concept of informal rulemaking is a unique American contribution to administrative law, one that promotes the rationality project. Indeed, Professor Kenneth Culp Davis called it "one of the greatest inventions of modern government."97 One author has suggested that, "the paradigmatic process for agency formulation of policy - informal rulemaking - is specifically geared to advance the requirements of civic republican theory." best promise for achieving the civic republican ideal of inclusive and deliberative

${ }_{93}$ Id. (citing Nat'l Tire Dealers \& Retreaders Ass'n v. Brinegar 491 F.2d 31, 37 (D.C. Cir. 1974)).

94 5 U.S.C. $\$ 553(2000)$.

${ }_{95}$ Exec. Order No. 12,866 Sec. 6(a)(3)(B)(ii), 58 Fed. Reg. 51,735 (Oct. 4, 1993). A major regulation that likely will "have an annual effect on the economy of $\$ 100$ million or more," adversely affects diverse sectors of the economy, creates inconsistencies with other agencies, alters rights of government entitlement holder, or raises "novel legal or policy issues." See id. Sec. 2 (f)(1)-(4).

${ }^{96}$ Peter L. Strauss, From Expertise to Politics: the Transformation of American Rulemaking, 31 WAKe FoREST L. REv. 745, 759-60 (1996).

971 Davis Administrative Law Treatise $§ 6.15$, at 283 (Supp. 1970).

${ }_{98}$ Mark Seidenfeld, A Civic Republican Justification for the Bureaucratic State, 105 HARV. L. REv. 1512,1560 (1992). 
lawmaking." 99 And such "deliberative rulemaking" is central to the rationality project.

It must be acknowledged that the "notice and comment" experiment cannot be revered as a total panacea. There is strong evidence that, in many cases, the notice and comment process is used more by regulated interests than the public. ${ }^{100}$ This should not surprise us as it is unlikely that institutional arrangements can, on their own, negate economic realities. Nonetheless, the "notice and comment" requirements do partake in the rationality project.

Section 553 of the APA requires that all new regulations be published as proposed regulations, that time be afforded for citizen comment, and that the agency respond to and reflect the comments in the final rule which should be accompanied by a concise statement of basis and purpose incorporating those comments. So far, so good. The remarkable feature of this so-called "notice-and-comment" rulemaking is that the public has a chance to comment on the rules before they are finalized. This contributes to rationality by obliging the agency to respond to citizen comments and to justify its approach. By bringing the interests of commentators into the conversation, prepromulgation comments provide agencies an opportunity to gain data that can improve the regulatory process, thus contributing to more "rational" regulation. But there is more. Courts have required that agencies respond meaningfully to citizens' comments when preparing the final regulation. ${ }^{101}$ They have further determined to take a "hard look"102 at the final rule, looking to see if the agency used incorrect statutory factors or failed to use correct factors in drafting the rule. Most importantly, the agency must give a "reasonable explanation" for making the decision it did. Furthermore, the record on which the agency acted must be available to the public so that we can all test the reasonableness of agency action. Thus the agency must show that it did not act "irrationally," or to use the technical locution, in an "arbitrary and capricious manner."103 By requiring agencies to give reasons, and courts to provide in depth review of those reasons, the notice and comment rulemaking process serves to promote rationality. ${ }^{104}$

99 Id.

${ }^{100}$ See Cornelius M. Kerwin, Rulemaking: How Government Agencies Write Law and Make Policy 182 (3d ed. 2003); see infra note 176.

${ }^{101}$ United States v. Nova Scotia Food Products Corp., 568 F.2d 240, 251 (2d Cir. 1977).

${ }^{102}$ See infra p. 41 and note 185.

${ }^{103} 5$ U.S.C. $\$ 706(2)(\mathrm{A})(2000)$.

${ }^{104}$ I should note that some commentators have suggested that "notice-and-comment rulemaking is to public participation as Japanese Kabuki theatre is to human passions-a highly stylized process 
Rational analysis, of course, requires knowledge. Thus the Clinton administration, through Executive Order 12,866, ${ }^{105}$ required all rulemaking agencies to "prepare an agenda of all regulations under development or review."106 This list requires agencies to coordinate the President's regulatory agenda. But it also forces agencies to list (and prioritize) their proposed regulatory actions. Such a planning requirement assists in developing rational analysis for the administrative state.

Another example of the rationality project is the increased use of cost-benefit analysis in rulemaking. The premise of this position is simple: it is unreasonable -indeed it is irrational- to promulgate a rule in which the costs are greater than the benefits. The argument is variously stated that Congress could not have meant to authorize an agency to act so irrationally, or at least that we can presume that Congress did not so intend, unless it makes a "clear statement" that that is its goal. Of course, the problem is that Congress has on many occasions acted to require regulations without seeming reference to costs. At one point, the Senate passed proposed legislation which required cost-benefit analysis as a precondition of agency rulemaking "except where the enabling statute pursuant to which the agency is acting directs otherwise." 107 Grants of statutory power to the Occupational Safety and Health Administration (OSHA), as example, to protect worker safety are not limited by the cost-benefit calculus. ${ }^{108}$ Neither are many of our anti-pollution laws. ${ }^{109}$

In recent years an effort was made by some jurists (most notably in the D.C. Circuit) to develop the notion that the default position in administrative law is one where benefits must exceed costs; that is to say, some form of cost-benefit analysis is the governing rule of reasonableness unless the statute chooses another rule. ${ }^{110}$

for displaying in a formal way the essence of something which in real life takes place in other venues." Frank B. Cross, Shattering the Fragile Case for Judicial Review of Rulemaking, 85 VA. L. Rev. 1243, 1312 (1999).

${ }^{105}$ Exec. Order No. 12,866, supra note 95.

${ }^{106} \mathrm{Id}$.

${ }^{107}$ Regulatory Reform Act, S. 1080, $97^{\text {th }}$ Cong. (1981). [Dr. Ginsberg (DC)].

${ }^{108}$ Or so the Supreme Court interpreted the OSHA statute in American Textile Manufacturers Inst. v. Donovan, 452 US 490, 519-20 (1981).

${ }^{109}$ See, e.g., Whitman v. Am. Trucking Ass'n, 531 U.S. 457, 471 (2001)(holding that the Clean Air Act bars the Environmental Protection Agency from considering costs of implementation when setting national ambient air quality standards).

110 "[C]ourts have often taken the word "reasonable" in a statute to require that burdens be justified by the resulting benefits." International Union, United Auto., Aerospace \& Agric. Implement Workers v. OSHA, 938 F.2d 1310, 1319 (D.C. Cir. 1991)(citing Consolidated Rail Corp. v. ICC, 646 F.2d 642,648 (D.C. Cir. 1981) for the proposition that safety measures must be reasonable, 
This position was explicitly rejected by the Supreme Court in Whitman v. American Trucking, ${ }^{11}$ but its spirit hovers in the background of academic discussion, creating a climate that suggests that cost-benefit analysis is proof of reasonableness.

Courts aside, the Executive branch (that is to say the President) since Ronald Reagan, has supported the idea that agencies should undertake cost-benefit studies before promulgating rules. ${ }^{112}$ In a series of Executive orders, recent presidentsRepublican and Democratic-have required agencies to undertake cost-benefit studies before promulgating "major" rules that have significant economic impact. ${ }^{113}$ President Bush left Clinton's executive order largely intact, including the provisions on cost-benefit analysis. ${ }^{114}$ However, President Bush did strengthen the role of the Office of Information and Regulatory Affairs (OIRA), a sub-agency of the Office of Management and Budget (OMB), ${ }^{115}$ by more aggressive use of OIRA's oversight

meaning "that they produce an expected safety benefit commensurate to their cost; and second, that when compared with other possible safety measures, they represent an economical means of achieving the expected safety benefit.")). In 1994, the D.C. Circuit had the opportunity to revisit International Union I and found that OSHA had conformed with nondelegation doctrine through a supplemental statement of reasons which, in part, "forc[ed] the agency at a minimum to adopt the cheapest standard that will achieve the desired level of safety." International Union, United Auto., Aero. \& Agric. Implement Workers of America, UAW v. OSHA, 37 F.3d 665, 668 (D.C. Cir. 1994) See also Am. Textile Mfrs. Inst. v. Donovan, 452 U.S. 490, 530 n. 55 (1981)(citing United Steelworkers of America v. Marshall, 647 F.2d 1189, 1265 (1981)(requiring that cost of standards regulating toxic materials not "threaten[] the competitive stability of an industry.")); American Petroleum Institute v. OSHA, 581 F.2d 493, 503 (5th Cir. 1978), aff'd, 448 U.S. 607 (1980)(OSHA was found to be obligated to determine if the expected benefits of a new benzene exposure limit had a reasonable relationship to the costs imposed by the standard); see also CASS R. SUNSTEN, THE Cost-Benefit State: The Future of Regulatory Protection 46-48 (2002).

111 Whitman v. Am Trucking Assr, supra note 109.

${ }^{112}$ Some might argue "since Jimmy Carter," as he required agencies promulgating regulations to engage in "rudimentary cost-effectiveness test[s]" and prepare descriptions of the problems they were addressing, alternative approaches, and "analysis of the potential economic impact of the regulation." However, "more substantial progress towards regulatory process reform came later [under the Reagan administration] when cost-benefit analyses were mandatory and incorporated into the regulation design process." See Murray Weidenbaum, Regulatory Process Reform, 20 REG. 20-26 (1997).

${ }^{113}$ Exec. Order No. 12,291, Sec. 3 (d), 46 Fed. Reg. 13,193 (Feb. 19, 1981)(Reagan), revoked by Exec. Order No. 12,866, Sec. 6 (a)(3)(B)(ii), 58 Fed. Reg. 51,735 (Oct. 4, 1993) (Clinton).

${ }^{114}$ Exec. Order No. 13,258, 67 Fed. Reg. 9,385 (Feb. 28, 2002). In this order, President Bush eliminates the role of the Vice-President from the regulatory review process.

${ }^{115}$ Robin Kundis Craig, The Bush Administration's Use and Abuse of Rulemaking, Part I: The Rise of OIRA, 28(4) ADMIN \& REG. L. News 8 (2003), available at http://www.abanet.org/adminlaw/news/ adlaw_summer03.pdf (last visited March 3, 2007). 
function. ${ }^{116}$ One manifestation of this is the unprecedented use of "prompt letters," proactive directives from OIRA "suggesting that an agency explore a promising regulatory issue for agency action, accelerate its efforts on an ongoing regulatory matter, or consider rescinding or modifying an existing rule." 117 As of May 12, 2005, twelve prompt letters had been issued. ${ }^{118}$

For its part, Congress has long debated the use of "cost-benefit analysis" in regulatory reform. ${ }^{119}$ While it has not instituted it generally, it has required its use in a number of circumstances including the "Unfunded Mandates Reform Act."120 This is a statute that affects agencies that promulgate regulations creating federal spending requirements for the states. Such agencies must provide a "qualitative and quantitative assessment of the anticipated costs and benefits" of such federal mandates when they result in an aggregated expenditure of 100 million dollars (indexed for inflation). ${ }^{121}$

The effort to ensure that the chosen regulatory approach "maximizes net benefits" 22 has led to the development of risk analysis, including a developing variant, riskrisk analysis. Risk-risk analysis suggests that in determining costs, one has to look not only at the risks of not acting, but also the risks of promulgating a government regulation. ${ }^{123}$

116 "Presidential oversight of the regulatory process, though relatively new, has become a permanent part of the institutional design of American government." Richard Pildes \& Cass Sunstein, Reinventing the Regulatory State, 62 U. CHI. L. REV. 1 (1995). Some commentators have suggested that the goal of OIRA is less ensuring rational administrative activity and more providing ammunition to support an administration's political (often anti-regulatory) policy references. See THOMAs McGarity, Reinventing Rationality 271-91 (1991). See also Joseph Cooper \& William F. West, Presidential Power \& Republican Government, 50 J. PoL. 864 (1998).

${ }^{117}$ Memorandum from John D. Graham, OIRA Administrator, to the President's Management Council (Sept. 20 2001), available at http://www.whitehouse.gov/omb/inforeg/oira_review-process.html (last visited March 3, 2007). All agencies must normally respond to prompt letters within thirty days. Id.

${ }^{118}$ Office of Management and Budget, OIRA Prompt Letters available at http://www.whitehouse. gov/omb/inforeg/prompt_letter.html (last visited March 3, 2007). The last prompt letter issued was November 16, 2004.

${ }^{119}$ See generally Cass Sunstein, Congress, Constitutional Moments, and the Cost-Benefit State, 48 STAN. L. REv., 247, 275-82 (1996).

${ }^{120} 2$ U.S.C. $\S \S 1501-1571(2000)$.

${ }^{121}$ Another example is the Safe Drinking Water Act Amendments of 1996, Pub. L. No. 104-182, 110 Stat. 1613 (codified as amended at 42 U.S.C. $\S \S 300 \mathrm{f}-300 \mathrm{j}-15$ (2005) and in scattered other sections of the U.S. Code (requiring use of cost-benefit analysis in establishing drinking water standards)).

${ }^{122}$ Exec. Order No. 12,866 Sec. 6(a)(3)(B)(ii), 58 Fed. Reg. 51,735 (Oct. 4, 1993).

${ }^{123}$ See John D. Graham \& JoHN WIENER, RISK v. Risk 227 (1995) for a discussion of "constructive ways, through the use of risk tradeoff analysis [("RTA")], to make better policies that provide more 
It must be recognized that there are serious issues with implementing the costbenefit principle. The most salient are laid out in a book by Cass Sunstein generally supportive of cost-benefit methodology. ${ }^{124}$ For example: 1) How do you assess costs or benefits to goods like health or beauty? That is to say, how do you monetize qualitative goods? 2) How do you compare different goods, like leisure time and wages? This is the so-called incommensurability problem. 3) How do you take into account the wide magnitude of the range of possible numbers? ${ }^{125}$ 4) How do you monetize or discount costs and benefits to future generations? ${ }^{126}$

These difficulties aside, the cost-benefit principle is an effort to make the regulatory process more subject to rational analysis. It is part of the rationality project-an effort to make "reason" a shadow substitute for democratic legitimacy. ${ }^{127}$

\section{The Transparency Project}

Until recently, the prevailing theory in England was that you needed a reason to receive information about what the government does. ${ }^{128}$ The presumption in America

protection of human health and the environment" and an "outline how RTA should be incorporated into decisionmaking about medical treatment and government regulation (including legislative, administrative, and judicial functions.)" See also Cass R. Sunstein, Precautions Against What? Availability Heuristic and the Cross Cultural Perception, 57 ALA. L. Rev. 75, 85-86 (2005). Sunstein asserts, "A great deal of evidence suggests the possibility that an expensive regulation can [actually] have adverse effects on life and health." Id.

${ }^{124}$ See Cass Sunstein, The Cost-Benefit State: The Future of Regulatory Protection 71-87 (2002).

${ }^{125}$ As example, an Environmental Protection Agency cost-benefit analysis of arsenic in drinking water resulted in figures of benefits that ranged between 13 million dollars and 3.4 billion dollars? This is the so-called interdeterminancy problem.

${ }^{126}$ See Matthew D. Adler \& Eric A. Posner, Cost Benefit Analysis: Legal Economic, and Philosophical Perspectives 270 (2001)(calling traditional cost-benefit analysis a "failure," but arguing that properly conceived the principle "is sufficiently accurate in tracking overall wellbeing and has sufficient other procedural virtues-it is relatively cheap to implement, relatively easy to monitor by oversight bodies, and relatively undemanding of agency expertise").

${ }^{127}$ We should note the cautionary note of Colin Diver that " $[t]$ he leading metaphor for comprehensive rationality is not the spirited debate of the town meeting but the scientist's lonely search for truth." Colin S. Diver, Policymaking Paradigms in Administrative Law, 95 Harv. L. REv. 393, 425 (1981).

${ }^{128}$ Change came with passage of the Freedom of Information Act, 2000, ch. 36 (Eng.). The United Kingdom's legislation is more limited in scope than the United States' Freedom of Information Act for two reasons. The first is that "a public authority [may] refuse a request for example because further information is required to enable it to comply (...); the cost of compliance would exceed 'the appropriate limit' $(. .$.$) ; the request is 'vexatious' or is a repeated request for the same information$ 
is exactly the opposite. Any person can request information and, generally speaking, does not have to show any specific need for the requested information. Indeed, the government needs a reason for not letting citizens have information. Such reasons are linked to specific statutory exemptions, which must be construed strictly. ${ }^{129}$

Starting in the 1960's, Congress passed a variety of laws designed to promote transparency in government. These include the Freedom of Information Act, ${ }^{130}$ the Federal Advisory Committee Act, ${ }^{131}$ and the Government in the Sunshine Act. ${ }^{132}$ Such laws serve "to ensure an informed citizenry, vital to the functioning of a democratic society, needed to check against corruption and to hold the governors accountable to the governed." 133 Transparency, then, would promote accountability and provide another support for legitimacy. For as James Madison noted in 1821, "[a] popular Government without popular information, or the means of acquiring it, is but a prologue to a Farce or a Tragedy; or perhaps both."134

There can be no doubt that the task of maintaining openness by both government and regulated entities has become far easier in the computer age. ${ }^{135}$ Using what has been described as "E-Government," 136 vast strides have been made in placing

..." The second is that a public authority is always in the position of deciding "whether the public interest in disclosure is outweighed by the public interest in concealment." $\mathrm{O}$. HOOD PHILLIPS AT al., Constitutional and Administrative LaW 615 (8th ed. 2001). The authors question "whether the Act with its extensive exemptions will ensure that there is more open government [because] there is plenty of opportunity provided by the Act to foster continued secrecy in government." Id. at 616. The European Union's Council of Ministers has also made efforts to improve transparency in its proceedings by establishing a rule for the publication of the provisional agendas of meetings in which it would be acting in a legislative capacity. 2000 O.J. (L 009) 22-23.

129 "Consistent with the Act's goal of broad disclosure, these exemptions have been consistently given a narrow compass." U.S. Dep't of Justice v. Tax Analysts, 492 U.S. 136, 151 (1989).

${ }^{130} 5$ U.S.C. $\S 552(2000)$.

1315 U.S.C. app. $\S \S 1-16(2000)$.

${ }^{132} 5$ U.S.C. $\$ 552(\mathrm{~b})(2000)$.

${ }^{133}$ Justice Marshall wrote this quote specifically regarding FOIA. See NLRB v. Robbins Tire \& Rubber Co., 437 U.S. 214, 242-43 (1978)(denying a FOIA request based on NLRB's "longstanding rule against prehearing disclosure of witness statements.").

${ }^{134}$ Letter from James Madison to W.T. Barry (Aug. 4, 1822), in The Complete Madison 337 (Saul Padover ed. 1953)

${ }^{135}$ Henry H. Perritt, Jr. President Clinton's Information Infrastructure Initiative: Community Regained?, 69 CHI-KENT L. REV. 991, 1011-13 (1994).

${ }^{136}$ E-government includes: e-publication, which is "by far the most important and widespread government use" involving "dissemination or 'publication' of information;" e-filing or "online filing of official documents, such as tax returns, corporate and non-profit filings, security interest filings...;" and e-procurement, or "government use of the Internet for buying and selling goods and services." See John C. Reitz, Section VI: Computers and Law: E-Government, 54 Ам. J. CoMP. L. 733, 734-35 (2006). 
information about the regulatory process on the web. ${ }^{137}$ An offshoot of e-government is what John Reitz terms "e-democracy." Reitz notes that the "ease of communication provided by computers and the Internet has the potential to revitalize the practices of democracy by bringing government officials into much easier and often more productive communication with the public."138

Given that computer files are clearly "documents" under the Freedom of Information Act, ${ }^{139}$ the prospect of widening the ambit of government disclosure inexpensively becomes a real possibility. Furthermore, the Electronic Freedom of Information Act Amendments of $1996^{140}$ created "electronic reading rooms"141 that offer extensive information to the public. The idea is that there is no point in requiring agencies allow interested parties to comment on proposed regulations without giving them the necessary data to make informed comments. This raises transparency to a new level.

Further, as electronic filing becomes more prevalent, affirmative dissemination of documents becomes easier. Now, "any person can obtain the records, leaving no paper trail to indicate that records on a subject had been downloaded by anyone."142 Thus, ease of access improves. Indeed, it is now possible to use hypertext to link files and documents that would affirmatively provide citizens with records of proposed government action allowing for a kind of affirmative transparency. In fact, courts have used this transparency concept to require full and robust "records" in rulemaking cases. $^{143}$

${ }^{137}$ Federal Register and Code of Federal Regulations, available at http://www.gpoaccess.gov/fr/index. html (last visited March 3, 2007).

${ }^{138}$ Id. at 735 .

${ }^{139}$ See Long v. IRS, 596 F.2d 362 (9th Cir. 1979).

${ }^{140}$ Pub. L. 104-231, 110 Stat. 3048 (1996), 5 U.S.C. $\$ 552$ (2000).

${ }^{141}$ U.S. Dep't of Justice, FreEdom OF INFORMATION Act Guide (2004), available at http://www.usdoj. gov/oip/readingroom.htm (last visited March 3, 2007).

${ }^{142}$ Home Box Office, Inc. v. FCC, 567 F.2d 9, 54-55 (D.C. Cir. 1977)(citing Citizens to Preserve Overton Park, Inc. v. Volpe, 401 U.S. 402, 420 (1971))(requiring disclosure of the full record before the agency at the time a rule is promulgated, stating that where "an agency justifies its actions by reference only to information in the public file while failing to disclose the substance of other relevant information... a reviewing court cannot presume that the agency has acted properly, but must ... perforce find [the agency's] actions arbitrary.").

${ }^{143}$ The development of electronic docketing of agency documents also raises knotty problems of privacy, copyright protection, censorship, security concerns as well. See Jeffrey S. Lubbers, The Future of Electronic Rulemaking: A Research Agenda, 27 Admin. \& Reg. L. News 6 (Summer 2002). 
Transparency can even serve as an alternative to regulation. Under appropriate circumstances, an agency may avoid direct regulation of regulated entities by requiring them to provide information to the general public. Often the informed public is able to exert sufficient influence on the regulated community to alleviate the need for further administrative activity. We can see this clearly in statutes like the Emergency Planning and Community Right to Know Act. ${ }^{144}$ For example, that Act requires companies to share information about hazardous materials. Often providing information to the public is all that is needed to influence the behavior of the regulated community.

The underlying theory is that if citizens have the facts they will be better able to make rational choices. If consumers know, for instance, that certain foods are genetically modified, they may not choose to purchase them, thus affecting business behavior. Similarly, notices placed on cigarettes warning of the risks of cancer will presumably reduce the incidence of smoking by affecting consumer behavior. Such government required transparency, it is hoped, will inform public opinion in ways that will mimic the rational voter, thus creating a democratic shadow or faux legitimacy for the administrative enterprise.

While the impetus for transparency has stalled somewhat after the tragedy of $9 / 11,{ }^{145}$ the resulting war on terror, and the concomitant concerns for the protection of critical-infrastructure, the thrust remains: a recognition that transparency in bureaucracy resolves, in part, the administrative state's legitimacy problem. ${ }^{146}$

\footnotetext{
1442 U.S.C. $\S \S 11001-05 ; 11021-23 ; 11041-50$ (2000).

${ }^{145}$ See Mary-Rose Papandrea, Under Attack: The Public's Right to Know and the War on Terror, B.C. L. Sch. Fac. Papers, 25:35 (2005). See Gina Marie Stevens, Homela.vd Security Act of 2002: Crutical Infrastructure Information Act (Congressional Research Service 2003); Marc Rotenberg, Privacy and Secrecy Afier September 11, 86 Mn入. L. REv. 1115 (2002); Kristen Elizabeth Uhl, The Freedom of Information Act Post- 9/11: Balancing the Public's Right to Know, Critical Infrastructure Protection, and Homeland Security, 53 AM. U.L. REv. 261 (2003); Tom Beirle \& Ruth Greenspan Bell, Don't Let "Right to Know" Be a War Casualty, 94 Christlax: SCI. MoNITOR 9 (Dec. 2001); Stephen Gidiere, Checks, Balances, and FOIA's $40^{\text {th }}$ Anniversary, USA Today, July 5,2006 , at $11 \mathrm{~A}$.

${ }^{146}$ While I have no knowledge as to any causal relationship, I should note that Israel too has since 1998 accepted in broad terms at least, the transparency principle in its own freedom of information law. Freedom of Information Law 5758-1998, L.S.I. 226, available in English at the Israeli Police website, http://police.gov.il/english/Information_Services/Law/xx_info_law. (last visited February $11,2007)$.
} 


\section{The Participatory Project}

The Participatory Project was an effort to increase public participation in the administrative rulemaking process. ${ }^{147}$ It was believed that such participation would increase the legitimacy of the rulemaking process by serving as a functional substitute for elected legislatures-thus solving the "democratic deficit" of administrative law. ${ }^{148}$ And as one proponent of interest-group participation has concluded, "[a]gency decisions made after adequate consideration of all affected interests...have... legitimacy based on the same principle as legislation."149 This approach "drew force from a general social trend that came to view agencies less as apolitical 'experts' administering a strictly rational process, and more as political bodies making choices among alternatives in response to social needs and political inputs."150

The revolution in participation was not a single, coherent movement. It included many disparate initiatives with widely variable effects. However, the driving force of the revolution was a lack of faith in the ability of established governmental institutions to understand the popular will and respond appropriately; again, a crisis of legitimacy. In the 1960 s and 1970 s, the American people experienced a transformative struggle for civil rights, unsatisfactorily explained assassinations of revered public figures, an unpopular war, political scandals, and a growing disaffection with government, which appeared unable to accomplish ambitious social objectives. ${ }^{151}$ The motives of those seeking to expand public participation ranged from a near-paranoid mistrust of the government's own motives, to a populist belief that direct input from citizens would improve the quality of the government's decisions. Also prominent was a faith in participation as a means of empowering and involving the disenfranchised and unrepresented which "to its defenders" reflected "a quest to expand the meaning and

${ }^{147}$ Some elements in the preceding projects also have "participatory" features, and some approaches partake of multiple projects. This exemplifies the point made supra, at note 50, that the various projects exist at the same time. See also infra text accompanying notes 155-57.

${ }^{148}$ Bressman, Beyond Accountability, supra note 50, at 475 (citing Richard B. Stewart, The Reformation of American Administrative Law, 88 HARV. L. REV. 1667, 1712 (1975)).

${ }^{149}$ Richard B. Stewart, The Reformation of American Administrative Law, 88 HARV. L. Rev. 1667, 1712 (1975).

${ }^{150}$ Strauss, supra note 96 , at 755.

${ }^{15 !}$ See Terry H. Anderson, The Sxuries (2nd ed. 2004); Leon F. Litwack, The Times They Are AChanging, in The Whole World's Watching: Peace and Social Justice Movements of the 1960s AND 1970s 5-8 (2001). 
practice of freedom."152 Participation in the rulemaking process is guaranteed by the APA's notice-and-comment provisions for informal rulemaking. ${ }^{153}$ Specifically, an agency must publish a notice of proposed rulemaking with a draft rule and leave the record open for public comment. ${ }^{154}$ The final rule must take these comments into account and agencies must explain in a "concise statement of basis and purpose" accompanying the final rule exactly how they responded to public comments. ${ }^{155}$

As one court has suggested, these requirements are "intended to insure that the process of legislative rule-making in administrative agencies is infused with openness, explanation, and participatory democracy." 156

In its heyday, the participation project led to a lowering of barriers of access to the courts ${ }^{157}$ and to intervention in agency proceedings. ${ }^{158}$ For a time, courts required various forms of judicially imposed public hearings crafted to meet a supersized notice and comment requirement in informal rulemaking. In the 1970s, the Supreme Court slapped down those efforts, precluding judicially created duties beyond those called for in the APA or enabling statute. ${ }^{159}$ They made clear that courts could not promote participation beyond that provided by statute.

${ }^{152}$ Sheldon Wolin, The Destructive Sixties and Postmodern Conservatism, in REASSESSLNG THE SLXIIES 129, 132 (Stephen Macedo ed., 1997).

${ }_{153} 5$ U.S.C. $\$ 553$ (b)-(c)(2000).

${ }^{154}$ The APA does not tell us how long the public gets to comment. For a discussion of enabling statutes that contain time periods see Jefrrey S. Lubbers, A Guide to Federal Agency Rulemaking, 27880, 296-98 (4th ed. 2006). E.O. 12,866, states that the period should "in most cases" be not less than 60 days, however that recommendation is not judicially enforceable. Exec. Order No. 12,866 Sec. 6(a)(1-2)(3) C.F.R. 644 (1993) reprinted as amended in Exec. Order No. 13,258, 67 Fed. Reg. 9384 (Feb. 28, 2002).

${ }^{155}$ United States v. Garner, 767 F.2d 104, 120 (5th Cir. 1985)(citing 5 U.S.C. $\$ 553$ (c)).

${ }^{156}$ South Carolina ex rel. Patrick v. Block, 558 F. Supp. 1004, 1015 (D.S.C. 1983)(emphasis added).

${ }^{157}$ See Ass'n of Data Processing Serv. Orgs., Inc. v. Camp, 397 U.S. 150 (1970)(opening standing rules); Clarke v. Sec. Indus. Ass'n, 479 U.S. 388 (1987); United States v. SCRAP, 412 U.S. 669 (1973). In Office of Communication of United Church of Christ v. FCC, 359 F.2d 994 (D.C. Cir. 1966), the D.C. Circuit held that a more inclusive standing requirement could only apply when plaintiffs sought to vindicate the broad public interest, not just private interests.

${ }^{158}$ As the American Bar Association Section of Administrative Law and Regulatory Practice states in its Black Letter Statement of Federal Administrative Law, 54 ADMIN. L. REV. 1, 31 (2002), "Agencies engaged in informal rulemaking may provide additional procedures beyond those established by the APA, other applicable statutes, and the agencies' own rules, but courts may not require them to do so."

${ }^{159}$ Vermont Yankee Nuclear Power Corp. v. Natural Res. Def. Council, Inc., 435 U.S. 519, 524, $544-$ 49 (1978) 
Moreover a number of recent participatory "project" efforts have excited democracy theorists, although the jury is still out as to their actual effect in promoting civic participation in the administrative process. One such technique is "negotiated rulemaking," by which the agency invites key "stakeholders" to sit at the table and participate in the drafting of the rule. ${ }^{160}$ Even when agencies do not make use of this approach, they may incorporate principles of negotiated rulemaking into their actions. ${ }^{161}$ Another technique is the federal government

${ }^{160}$ Jefferey S. Lubbers, Approaches to Regulatory Reform in the United States: A Response to the Remarks of Professors Levin and Freeman, 83 Wash. U. L.Q. 1893, 1904 n.33 (2005)(Negotiated rulemaking remains a source of significant debate. Critics have argued that employing regneg "allows agencies to transfer too much control to private parties," see William Funk, When Smoke Gets in Your Eyes: Regulatory Negotiation and the Public Interest-EPA's Woodstove Standards, 18 Envtl. L. 55 (1987); Susan Rose-Ackerman, Comment, Consensus Versus Incentives: A Skeptical Look at Regulatory Negotiation, 43 DUKE L.J. 1206 (1994); and William Funk, Bargaining Toward the New Millennium: Regulatory Negotiation and the Subversion of the Public Interest, 46 DuKE L.J. 1351 (1997), while Cary Coglianese, has empirically challenged "the basic assumption that regulatory negotiation has produced faster and less litigated rules." Cary Coglianese, Assessing Consensus: The Promise and Performance of Negotiated Rulemaking, 46 DUKE L.J. 1255 (1997); Cary Coglianese, Assessing the Advacacy of Negotiated Rulemaking: A Response to Philip Harter, 9 N.Y.U. ENVTL. L.J. 386 (2001). Conversely, authors of other studies have strenuously defended reg-neg, Philip J. Harter, Assessing the Assessors: The Actual Performance of Negotiated Rulemaking, 9 N.Y.U. ENVTL. L.J. 32 (2000)(inciting a response by Professor Coglianese); Laura I. Langbein \& Cornelius M. Kerwin, Regulatory Negotiation Versus Conventional Rule Making: Claims, Counterclaims, and Empirical Evidence, 10 J. PuB. ADMm. RES. \& THEORY 599 (2000)(finding that participants felt negotiated rules were superior, and more likely to be implemented, than conventional rules); Jody Freeman \& Laura I. Langbein, Regulatory Negotiation and the Legitimacy Benefit, 9 N.Y.U. ENVTL. L.J. 60 (2000)(finding significant legitimacy benefit); Philip J. Harter, A Plumber Responds to the Philosophers: A Comment on Professor Menkel-Meadow's Essay on Deliberative Democracy, 5 Nev. L.J. 379 (2004-05). See also Andrew P. Morriss, Bruce Yandle, \& Andrew Dorchak, Choosing How to Regulate, 29 Harv. ENVTL. L. REv. 179, 195-202 (2005)(finding good arguments on both sides, but generally siding with Coglianese on empirical debate with Harter); Mark Seidenfeld, Empowering Stakeholders: Limits On Collaboration As The Basis For Flexible Regulation 41 Wm. \& MARY L. Rev. 411, $458(2000)$ ("The collaborative process is most promising, however, if used as a tool to guide agency discretion, rather than as an alternative mechanism to promulgate regulations backed by the coercive power of the state."); and Siobhan Mee, Comment, Negotiated Rulemaking and Combined Sewer Overflows (CSOs): Consensus Saves Ossification?, 25 B. C. ENvTL. AfF. L. Rev. 213 (1997)(lauding the success of this particular reg-neg).

${ }^{161}$ For example when the Federal Highway Administration revised its Manual on Uptown Traffic Control Devices in May 2001, it "delegated authority to a group whose membership was drawn from the American Association of State Highway Officials, the National Association of Country Engineers, the American Public Works Association and other organizations with expertise in the operation of traffic control devices." Steven J. Balla, Between Commenting and Negotiation: The Contours of Public Participation in Agency Rulemaking, 1 I/S 59, 80 (2004/2005). Much of this group's work was incorporated into the notices of proposed rulemaking published in the Federal Register. 
E-Rulemaking Initiative, ${ }^{162}$ spurred by the E-Government Act of $2002^{163}$ and the development of the Federal Docket Management System, ${ }^{164}$ a centralized federal system designed to spur citizen access to the rulemaking process. The centerpiece of this effort, Regulation.gov, is designed to assist citizens to locate and submit electronic documents on proposed agency regulation. ${ }^{165}$

Democracy theorists have begun to speculate how participatory models can be used in administrative law. Some have drawn from the deliberative democracy proposals of democratic theorists, like Jim Fishkin, ${ }^{166}$ to support a two-tier rulemaking system. Besides traditional notice-and-comment rulemaking, the system would offer enhanced participation "involv[ing] a series of administrative jury deliberations (juries featuring

${ }^{162}$ See Regulations.gov: Your Voice in Federal Decision-making, http://www.regulations.gov/ fdmspublic/component/main (last visited March 3, 2007).

${ }^{163}$ E-Government Act of 2002, Pub. L. 107-347, 116 Stat. 2899. The E-Government Act "fill(s) a gap in the APA, which does not by express terms require the agency to make the comments its (sic) receives during the comment process available to the public." John C. Reitz, Section VI: Computers and Law: E-Government, 54 AM. J. CoMP. L. 733, 744 (2006). FirstGov.gov, a "searchable entry point for filing comments in any federal rulemaking proceeding" was introduced by the Clinton Administration in 2000. John C. Reitz, Section VI: Computers and Law: E-Government, 54 AM. J. Comp. L. 733, 744 (2006). Orly Lobel, The Renew Deal: The Fall of Regulation and the Rise of Governance in Contemporary Legal Thought, 89 MinN. L. Rev. 342, 360 (2004). Essentially, the E-Government Act codified FirstGov.gov, and in addition, created a new office within the Office of Management and Budget devoted to these concerns. James W. Conrad Jr., The Information Quality Act-Antiregulatory Costs of Mythic Proportions?, 12 Kan. J.L. \& PuB. Pol'y 521, 527 (2003). See also E-Govermment Act of 2002, Pub. L. 107-347, 116 Stat. 2899, 2902-03. This office, the Office of Electronic Government and Technology, is headed by a Chief Information Officer. Its mission is "to shift perspective, move to citizen-centered services and create a real electronic government." See Office of Electronic Government and Technology, available at http:// www.estrategy.gov/flashmain.cfn?action=main (follow "About Us" hyperlink)(last visited July 12, 2006)(quoting Deputy Associate Administrator, Mary Mitchell).

${ }^{164}$ Establishment of a New System of Records Notice for the Federal Docket Management System, 70 FED. REG. 15,086 (Mar. 24, 2005).

${ }^{165}$ See George Papendreou, e-Democracy for the European Union, IPTS Report (June 2003); see Share I/S at n.54. The effort at e-democracy is not limited to the U.S. Spurred by Greece, the EU has promoted an e-democracy initiative in 1994.

${ }^{166}$ James S. Fishkin, Deliberative Polling: From Experiment to Community Resource, in THE Deliberative Democracy Handbook: Strategies for Effective Crvic Engagement in the TwentyFIRST CENTURY, 68 (2005); See also James S. Fishkin, The Televised Deliberative Poll: An Experiment in Democracy, 546 AnNals 132, 134-37, 140 (1996); James S. Fishkin, The Case for a National Caucus: Taking Democracy Seriously, ATLANTIC 16-18 Aug. 1988; James S. Fishkin, Framework of Analysis and Proposals for Reform: A Symposium on Campaign Finance: Conflicting Ideals of Democracy: Reflections on Reform of the Democratic Process, 18 HofsTRA L. Rev. 395, 405-10 (1989)(describing the "National Caucus" concept); Bruce E. Cain, The Internet in the (Dis)Service of Democracy?, 34 Loy. L. Rev. 1005, 1016 (2001). 
stakeholders and members of the general public)." 167 "The more public participation in the promulgation of an agency rule, the more deference that rule should receive when it is challenged in court." 168 However, scholars differ as to the potential success online systems enabling enhanced participation will achieve. While Orly Lobel has noted the potential of e-rulemaking to enhance legislative transparency by spawning "deliberative forums... (and) panels of citizens, like traditional juries, that would advise about rulemaking," 169 not all commentators agree. For example, Beth Noveck argues that this heightened transparency will simply "increase the incentive for agencies and the public to 'work around' technological mechanisms and shift away from transparent toward less democratic, but more manageable models of back-room consultation."170 Quoting from Dan Esty, Noveck further points out that "giving 'voice' to more people does not guarantee better policymaking."171

For a time, legislatures stepped up to the plate, requiring (as in the Magnuson-Moss Warranty Act $)^{172}$ agencies to pay the expenses of citizens to participate in hearings under the Act. ${ }^{173}$ However, in recent years, the legislature's enthusiasm for maximum public participation has somewhat waned. We have seen, in Sidney Shapiro's words, efforts to "limit participation of interest groups representing regulatory beneficiaries." That comes, I suggest, from a recognition that participation and especially maximal possible participation cannot solve the democratic deficit in administrative law. ${ }^{175}$

${ }^{167}$ David Fontana, Reforming the Administrative Procedure Act: Democracy Index Rulemaking, 74 FORDHAM L. REv. 81, 82 (2005).

${ }^{168} \mathrm{Id}$.

${ }^{169}$ Orly Lobel, The Renew Deal: The Fall of Regulation and the Rise of Governance in Contemporary Legal Thought, 89 Minn. L. REv. 342, 360-61 (2004).

${ }^{170}$ Beth Noveck, The Electronic Revolution in Rulemaking, 53 EMORY L.J. 433, 443 (2004).

${ }^{171} \mathrm{Id}$.

${ }^{172}$ Pub. L. 93-637, 88 Stat. 2183 (1975), also known as the "Lemon Law."

${ }^{173} \mathrm{Id}$. at Sec. 202 (a), Sec. 18 (h)(1), 88 Stat. 2197-98.

${ }^{174}$ Sidney Shapiro, Pragmatic Administrative Law, Issues IN Legal ScholarshIP: THe Reformation of AmERICAN Administratrve Law (2005), available at http://0-www.bepress.com.columbo.law.cua. edu:80/ils/ iss6/art1 (last visited March 5, 2007).

${ }^{175}$ We must recognize some caveats to this paen to participatory values. As Kenneth Ward notes, "weaker interests today (many small businesses, consumer groups) have very little chance of influencing, say, rulemaking in their favor over the wishes of the powerful interests (for example, IBM, General Motors, ITT, AMA), because virtually all the wild cards in the game have already been dealt to the big interest." Kenneth F. Ward, Administrative Law in the Polmical System 233 (2004). Further compounding the problem, "big interests are not only too much for the competitors but too much for the regulatory agencies as well." Id. at 233. 
Indeed, one Italian scholar has underscored that "participation is more associated with good administration than democracy."176

Academics may love the use of interest group representation in administrative decision making. Indeed, one of my Conference colleagues on this panel has proposed such a participatory (or interest based) approach to Israeli administrative law. ${ }^{177}$ However, the interest representation approach can easily turn administrative agencies into venues for interest group pluralism. This is only a polite term for lobbying by special interests, thus introducing the problems of the legislative process into the executive branch. ${ }^{178}$

For good or ill the pressure for participatory democracy that underlay the French street demonstrations of May 1968 and the American student movement of the 1970s has lost some but not all of its allure. And while the participatory project is no longer seen as conclusive proof of legitimacy in administrative law, it is important nonetheless. ${ }^{179}$ That it has reached its apogee, however, reflects the problem of squaring the democratic impulse with the logic of the administrative state.

\section{E. The Problem of Deference}

How does the practice of deference fit into my argument that the American political system distrusts bureaucracy? By deference, of course, I mean the rigor by which

${ }^{176}$ Fabrizio Fracchia, Administrative Procedures and Democracy: The Italian Experience, 12 IND. J. Global Legal Stud. 589.592 (2005). Fracchia states, "[s]ome scholars suggest that procedural participation can compensate for this democratic defeat. I do not agree with this view." Id. at 594.

${ }^{177}$ Daphne Barak-Erez, The Administrative Process as a Domain of Conflicting Interests, 6 THEORETICAL INQ. L. 193 (2005); "the decision-making process of the administrative agency in actuality entails a fundamental balancing of conflicting interests, similar to that "intended by the legislature." Id. at 196.

${ }^{178}$ Indeed, we should remember that according to Richard Stewart, "there is no feasible means to ensure that all stakeholders with significant interest are represented in the administrative process ...." The potential gaps in representation are "exacerbated by "agency costs" which are only heightened by greater participation. In the end, these higher costs "would increase the difficulty of equalizing the influence of diffuse interest groups who were now allowed to participate in agency proceedings because of the inherent advantages of focused interest groups in organizing and raising the money necessary for such participation." See Mark Seidenfeld, The Quixotic Quest for a Unified Theory of the Administrative State, 6 IssUES N LEGAL SCHOLARSHIP 2 (2005) available at http://www.bepress.com/ils/iss6/art2/ (last visited November 25, 2006).

${ }^{179}$ See StEPHEN BREYER, ACTIVE LrBerTy 15-16 (2005)(promoting the concept of "active liberty" defined as "a sharing of a nation's sovereign authority among its people" through political participation.). 
courts review agency decisions (that is to say, decisions made by the bureaucracy). At first glance, theories of heightened deference appear to frustrate efforts to confront the "democratic deficit." However, I would argue to the contrary, that theories of heightened deference in fact contribute to resolving the challenge of the democratic deficit.

In the early years of the "administrative state," critics did not trust administrative agencies to follow "the rule of the law" and sought independent de novo review of agency determinations. ${ }^{180}$ Over time, this distrust of the agency adjudication process ameliorated and we saw high levels of judicial deference to agency expertise. ${ }^{181}$ This was the way of New Deal jurisprudence, ${ }^{182}$ which began to be cut back, albeit mildly, with the passage of the APA. ${ }^{183}$ In that Act, Congress, in Justice Frankfurter's words, set a 'mood' of somewhat increased review, ${ }^{184}$ which was itself ratcheted up with the development of the "hard look" doctrine by the judges of the DC Circuit. ${ }^{185}$

${ }^{180}$ See Cincinnati, N. O. \& T. P. R. Co. v. Interstate Commerce Com., 162 U.S. 184, 196 (1896)(“the findings of the Commission shall be regarded as prima facie evidence"); see also Kentucky \& I. Bridge Co. v. Louisville \& N. R. Co., 37 F. 567, 612-614 (C.C.D. Ky. 1889)(where the court indicated that facts investigated and reported by the interstate commerce commission were only prima facie evidence in subsequent judicial proceedings, which are considered "original and independent proceeding[s]" that "determine[] the cause de novo").

${ }^{181}$ The high water mark for such deference when it came to rulemaking was Pacific States Box \& Basket Co. v. White, 296 U.S. 176, 185 (1935)(quoting Borden's Farm Products Co. v. Baldwin, 293 U.S. 194, 209 (1934))("[I]f any state of facts reasonably can be conceived that would sustain [the order], there is a presumption of the existence of that state of facts, and one who assails [that presumption] must carry the burden of showing ... that the action is arbitrary.").

${ }^{182}$ See Daniel J. Gifford, The New Deal Regulatory Model: A History of Criticisms and Refinements, 68 Man. L. REv. 299, 306, 1983 (discussing regulatory mechanisms of the new deal era and the deference given to agency administrators); Robert L. Rabin, Legitimacy, Discretion, and the Concept of Rights, 92 YALE L.J. 1174, 1178-80 (1983)(discussing the new deal era and rise of administrative expertise). See generally James M. LANDis, The Administrative Process (1938)(explaining the rise of faith in administrative expertise during the New Deal era).

${ }^{183}$ Administrative Procedure Act, 5 U.S.C. $\S 706(2)$ (E) (1966). For a history of the APA, see Walter Gellhorn, The Administrative Procedure Act: The Beginnings, 72 VA. L. REv. 219 (1986)(describing the actions that led to the 1946 Administrative Procedure Act).

${ }^{184}$ Universal Camera Corp. v. NLRB, 340 U.S. 474, 477(1951). See generally, Alfred S. Neely, Justice Frankfurter, Universal Camera and A Jurisprudence of Judicial Review of Administrative Action, 25 U. ToL. L. REv. 1 (1994)(reviewing Universal Camera and criticizing Justice Frankfurter's opinion on judicial review of administrative finding of fact).

${ }^{185}$ Citizens to Preserve Overton Park Inc. v. Volpe, 401 U.S. 402, 415 (1971), is credited with refining the hard look doctrine, created by Judge Leventhal in Greater Boston Television Corp. v. FCC, 444 F.2d 841 (D.C. Cir. 1970), cert. denied, 403 U.S. 923 (1971), by requiring "probing, in-depth review" of agency action. See also Nat'l Lime Ass'n v. EPA, 627 F.2d 416, 451 n.126 (D.C. Cir. 1980); Pikes Peak Broad. Co. v. FCC, 422 F.2d 671, 682 (D.C. Cir. 1969)); Colloquy, The Fifth Annual Robert C. Byrd Conference on the Administrative Process: The First Year of Clinton/Gore: 
After enacting the APA, Congress once again entered the fray with proposals (that never became law) to increase judicial review of regulatory agency activity. Between 1975-80, Congress tried numerous times to amend the APA to require that courts decide all relevant questions of law de novo, ignoring agency interpretations. Those bills were styled Bumper Amendments after Senator Dale Bumpers of Arkansas. ${ }^{186}$ In the 1990 s, various iterations of the conservative regulatory reform efforts, culminating in the Comprehensive Regulatory Reform Act of 1995 (S. 343)(introduced by Senator Bob Dole but never passed by the Senate) ${ }^{187}$ sought to codify "a relatively stringent version of the Chevron doctrine."188 Essentially, the first permutation of the bill sought to create "a sort of neo-Bumpers Amendment ... [attempting] to make a more searching and potent weapon against agency overreaching"189 in order to impose "new curbs on agency discretion."190 The bill offered extensive, some say innumerable, opportunities for judicial review as a way of checking agency action. For example, it provided for review of the substance as well as the form of agency cost-benefit analyses and agency decisions to characterize rules as "major" or not. ${ }^{191}$

Reinventing Government or Refining Reagan/Bush Initiatives?, 8 AdmIN. L.J. AM. U. 23, 41 (1994). See also Mark Seidenfeld, A Syncopated Chevron: Emphasizing Reasoned Decisionmaking in Reviewing Agency Interpretations of Statutes, 73 TEXAS L. REV. 83, 128-29 (1994)(“[T]he "hard look' test ... asks the courts to steep themselves in agency policy and the substantive debate framing the issue under consideration to ensure that the agency below gave a 'hard look' to all factors relevant to its decision.").

${ }^{186}$ See the text as of the end of 1980, 126 Cong. Rec. S13, 877 (daily ed. Sept. 30, 1980) and as passed by the Senate in an earlier form, 125 Cong. Rec. S12, 145 (daily ed. Sept. 7, 1979). For a discussion of the Bumpers Amendment, see James T. O'Reilly, Deference Makes a Difference: A Study of Impacts of the Bumpers Judicial Review Amendment, 49 U. CrN. L. Rev. 739 (1980); Ronald M. Levin, Review of "Jurisdictional" Issues Under the Bumpers Amendment, 1983 DuKE L.J. 285, 358 (1983); Cynthia R. Farina, Statutory Interpretation and the Balance of Power in the Administrative State, 89 Colum. L. Rev. 452, 473-74 (1989).

${ }^{187}$ S. 343, 104 th Cong. (1995). The history of the Dole bill is succinctly described in Cass Sunstein, Legislative Foreword: Congress, Constitutional Moments, and the Cost-Benefit State, 48 STAN. L. Rev. 247, 277-282 (1994).

${ }^{188}$ Ronald M. Levin, Scope of Review Legislation: The Lessons of 1995, 31 WAKE FOREST L. REV. 647, 655-56 (1996)(citing Regulatory Revisions: Hearings on S. 343 Before the Subcomm. On Admin. Oversight and the Courts of the Senate Judiciary Comm., 104th Cong., 1st Sess. (1995)(statement of George C. Freeman, Jr., \& Philip J. Harter, Cochairs, American Bar Association's Working Group on Regulatory Reform)("This section essentially codifies the 'hard look' line of Chevron cases.")).

${ }^{189} \mathrm{Id}$.

${ }^{190} I d$. at 657.

${ }^{191} \mathrm{Id}$. (proposing 5 U.S.C. $\S \S 622-25$ ). These legislative proposals also promote accountability of a different sort by requiring an agency to undertake a review of the rules' efficacy within ten years 
While the Congress undertook to limit deference through a series of failed legislative initiatives, the Court in 1984, in Chevron U.S.A. v. National Resources Defense Council, moved from "substitution of judgment" or "weak deference" in judicial review of legal question to a more permissive or deferential stance. Chevron ${ }^{192}$ stated that:

When a court reviews an agency's construction of the statute which it administers, it is confronted with two questions. First, always, is the question whether Congress has directly spoken to the precise question at issue. If the intent of Congress is clear, that is the end of the matter; for the court, as well as the agency, must give effect to the unambiguously expressed intent of Congress. If, however, the court determines Congress has not directly addressed the precise question at issue, the court does not simply impose its own construction on the statute, as would be necessary in the absence of an administrative interpretation. Rather, if the statute is silent or ambiguous with respect to the specific issue, the question for the court is whether the agency's answer is based on a permissible construction of the statute. ${ }^{193}$

Chevron soon became the "default" position for judicial review of administrative agency action. It "signified a fundamental paradigm-shift that redefined the rules of courts and agencies when construing statutes over which agencies have been given interpretive rights." 194 The gravamen of Chevron was to give "more policy discretion and law-making authority to administrative agencies, most of which are part of the

after promulgation, $i d$. at $\S 3$ (a), and by enacting "look-back" provisions, by which a member of the regulated community can ask or require an agency to review the efficacy of a particular rule at any time, perhaps even when the rule is about to be enforced on that party. See id. at $\S 4$ (a)(including a "look-back" provision as part of the proposed comprehensive Regulatory Reform Act). This ensures that the agency decision does not stray too far from contemporary congressional will. Further, the Dole bill not only allowed for more extensive judicial review of agency actions, it would also have required that proposed agency regulation be brought back to Congress and "laid on the table," where Congress would have the opportunity to enact a "two-house" veto, clearly constitutional even under Chadha. Id. (proposing U.S.C. § 801). See INS v. Chadha, 454 U.S. 812 (1981).

${ }^{192}$ Chevron U.S.A. v. National Resources Defense Council, 467 U.S. 837 (1984).

${ }^{193} \mathrm{Id}$. at 842-43.

${ }^{194} \mathrm{E}$. Donald Elliott, Chevron Matters: How the Chevron Doctrine Redefined the Roles of Congress, Courts, and Agencies in Environmental Law, 16 VILL. ENVTL. L. J. 1 (2005). 
Executive Branch."195 As such, Chevron has been called the "counter-Marbury of the administrative state." 196

On the surface, this move to heightened deference reflects a recognition of the need for agency discretion due to agency expertise; there is much language in Chevron to justify that approach. ${ }^{197}$ Nonetheless, I would argue that the justifications put forward in Chevron for 'privileging' agency determinations reflect as much a populist as a technocratic bias. ${ }^{198}$ This populist rationale behind Chevron "anchored" the approach of Chevron "in the theory of majoritarianism," 199 "invoking democratic theory as a basis of requiring deference to executive interpretations." ${ }^{200}$ Under this populist rationale, the executive is the most democratically legitimate branch (as the president is elected by the entire nation). ${ }^{201}$ Indeed, as Justice Breyer (dissenting) wrote in Brown \& Williamson, "Presidents, just like Members of Congress, are elected by the public. Indeed, the President and Vice President are the only public officers whom the entire nation elects." ${ }^{202}$ Since the administrative agencies are accountable to a

${ }^{195} \mathrm{Id}$. at 5 .

${ }^{196}$ See Cass Sunstein, Law and Administration After Chevron, 90 Colum. L. REV. 2071, 2075 (1990).

The reference, of course, is to Marbury v. Madison, 5 U.S. (1 Cranch) 137, 177 (1803).

${ }^{197}$ See Chevron, supra note 192, at 865 ("Perhaps [Congress] consciously desired the Administrator to strike the balance [between conflicting policies] at this level, thinking that those with great expertise and charged with responsibility for administering the provision would be in a better position to do so....").

${ }^{198}$ See id. at 865-66 (1984)("Judges are not experts in the field, and are not part of either political branch.... While agencies are not directly accountable to the people, the Chief Executive is, and it is entirely appropriate for this political branch of the Government to make such policy choices....").

${ }^{199}$ Jane S. Schacter, Metademocracy: The Changing Structure of Legitimacy in Statutory Interpretation, 108 HaRv. L. REv. 593, 614 (1995).

${ }^{200}$ Thomas W. Merrill, Judicial Deference to Executive Precedent, 101 Yale L.J. 969, 978 (1992) ("This new emphasis on democratic theory was important to the doctrinal framework because it supplied the justification for switching the default rule from independent judgment to deference."). We must remember that while Chevron deference "is not a rule of constitutional law per se,... it is nevertheless presumes an important separation of powers principle." LAURENCE H. TRIBE, American Constitutional LaW 994 (3d ed. 2000). As Judge Silberman has point out "That is not to say that Chevron is in any sense constitutionally dictated by the separation of powers." As Justice Scalia has observed, for any given statute, Congress could rebut Chevron's presumption-. that ambiguous statutes should be interpreted by the agency rather than the judiciary-by stripping the agency of deference. Laurence H. Silberman, Chevron-Intersection of Law \& Policy, 58 Geo. Wash. L. Rev. 821, 824 (1990).

${ }^{201}$ This is not completely accurate because of the Electoral College, see U.S. Consr. AMEND. XII. For evidence of this, see Bush v. Gore, 531 U.S. 98 (2000).

${ }^{202}$ FDA v. Brown \& Williamson Tobacco Corp., 529 U.S. 120, 190 (2000)(Breyer, J., dissenting). 
president who is popularly elected, ${ }^{203}$ their judgments should receive deference from the judiciary who are politically unaccountable by constitutional design. ${ }^{204}$ Thus, " $[t]$ he agencies - even independent ones-have superior political standing to the lifetenured federal judiciary in performing that policy making function. ${ }^{205}$

Indeed, as Justice Stevens writes in Chevron:

\begin{abstract}
[A]n agency to which Congress has delegated policy-making responsibilities may, within the limits of that delegation, properly rely upon the incumbent administration's views of wise policy to inform its judgments. While agencies are not directly accountable to the people, the Chief Executive is, and it is entirely appropriate for this political branch of Government to make such policy choicesresolving the competing interests which Congress itself either inadvertently did not resolve, or intentionally left to be resolved by the agency charged with the administration of the statute in light of everyday realities. ${ }^{206}$
\end{abstract}

Even in cases like Brown \& Williamson, ${ }^{207}$ where the Court did not defer to the agency, the Court's explanation was phrased in terms of democratic legitimacy-

${ }^{203}$ Richard J. Pierce, Democratizing the Administrative State (October 2005). GWU Law School Public Law Research Paper No. 173. Abstract available at: http://ssrn.com/abstract=839227 (last visited March 25, 2007).

${ }^{204}$ See U.S. CONST. ART. III, $\S 1$, cl. 2 ("The Judges, both of the supreme and inferior Courts, shall hold their Offices during good Behaviour, and shall, at stated Times, receive for their Services, a Compensation, which shall not be diminished during their Continuance in Office.").

${ }^{205}$ Silberman, supra note 200, at 823. See also Mark Seidenfeld, A Syncopated Chevron: Emphasizing Reasoned Decisionmaking in Reviewing Agency Interpretations of Statutes, 73 TEX. L. REv. 83, 97 (1994)("Chevron implicitly justifies this transfer of responsibility largely on the theory that agencies are more politically accountable than courts.").

${ }^{206}$ Chevron, supra note 192 at 865-66. Indeed, as one commentator has suggested, "[a]ccording to Chevron, ... it is always better to have an accountable actor make policy than a non-accountable one. A court, as grand enforcer of democratic norms, must surrender and reassign its own interpretive authority to a body perceived to have a better democratic pedigree." Schacter, supra note 199 , at 617 . In contrast, Marc Seidenfeld argues that Chevron resolves the accountability problem by implementing a form of interest group pluralism. Seidenfeld "views the democratic process as a competition between various interest groups for government- provided benefits." Seidenfeld, supra note 178 , at 97 . Indeed, "according to the pluralistic democracy model, agencies should make political choices that satisfy the demands of the interest groups that make up the constituency of the directly accountable branches of government- Congress and the President. This is the precise role that the Chevron court sees agencies playing." Id. at 99-100. Rust v. Sullivan, 500 U.S. 173 (1991) stands for that proposition.

207529 U.S. at 161. 
specifically that some questions are too extraordinary to presume that Congress had delegated authority to the agency to make the policy call. This approach has been denominated the 'major question' exception to Chevron deference. ${ }^{208}$ And indeed, in such cases (where deference is rejected), it has been argued that the Court was responding to a perception that the administration was acting in ways that while technically legal were viewed (by some) as undemocratic. ${ }^{209} \mathrm{Or}$, as Bressman puts it, a condition of deference is "that an agency not only possess delegated authority but exercises such authority in a democratically reasonable fashion."210

By locating authority in the president - the one official who speaks for all the people - the Chevron approach to statutory interpretation deftly avoids the legitimacy problem traditionally faced by administrative law. ${ }^{211}$

${ }^{208}$ The "major question" exception is discussed in Cass R. Sunstein, Chevron Step Zero, 92 VA. L. REV. 187, 193 (2006), where he asserts that through a "trilogy" of outlier cases (FDA v. Brown \& Williamson Tobacco Corp., 529 U.S. 120, 132-33, 159-61 (2000); Babbitt v. Sweet Home Chapter of Cmtys. for a Great Or., 515 U.S. 687, 703-08 (1995); MCI Telecomm. Corp. v. AT\&T Co., 512 U.S. 218, 228-34 (1994)), the Court suggests the "possibility that deference will be reduced, or even nonexistent, if a fundamental issue is involved, one that goes to the heart of the regulatory scheme at issue. The apparent theory is that Congress should not be taken to have asked agencies to resolve those issues." For an alternative theory, see Lisa S. Bressman, Deference and Democracy, Geo. WASH. L. Rev. (forthcoming 2007)(citing Gonzales v. Oregon, $126 \mathrm{~S}$. Ct. 904 (2006))[hereinafter Bressman, Deference], arguing that the real issue the Court confronted revolved around the agency's "undemocratic" use of its authority, rather than whether Congress had delegated the authority in the first place.

${ }^{209}$ Bressman, Deference, id.

${ }^{210} \mathrm{Id}$.

${ }^{211}$ There is, of course, another source of democratic legitimacy - the Congress. And one may wonder why one might not look to Congress as a way of avoiding the democratic deficit problem. Most scholars who support Chevron argue that democratic accountability is more likely to be found in the president than the Congress. The president is seen as having a national constituency and thus is more responsive than Congressmen to the electorate as a whole. See JERRY L. Mashaw, Greed, Chaos, ANd Governance 152 (1997)(asserting that President is more responsive to public preferences because he deals with national issues and has no specific constituency negotiating benefits for votes). Supporters of presidential accountability tend to denigrate the congressional branch as a source of democratic accountability. Tracking recent application of "public choice theory" they argue "that the legislature will produce too few laws that serve truly public ends, and too many laws that serve private ends." William N. Eskridge, Jr., Symposium on the Theory of Public Choice: Politics Without Romance: Implications of Public Choice Theory for Statutory Interpretation, 74 VA. L. REv. 275, 277 (1988). Public choice theory, they would argue, "posits that legislatures fall prey to endless cycling and agenda manipulation in any voting scheme [and] suggests that, even under ideal circumstances and given the best intentions, Congress may be unable to arrive at constitutional decisions that are wholly consistent with the preferences of a majority of Congress' members. Note, Should the Supreme Court Presume that Congress Acts Constitutionally? The Role of the Canon of Avoidance and Reliance on Early Legislative Practice in Constitutional Interpretation, 116 HaRV. L. REV. 1798, 1800 (2003). A less theoretical critique 
This effort to employ democratic legitimacy as the justification of Chevron has operational consequences. For example, on that model, Chevron "explicitly recognized an incumbent administration's policies as a legitimate factor that might influence an agency to alter its interpretation of ... a statutory term." ${ }^{212}$ This would explain Professor Richard Pierce's ${ }^{213}$ critique of two recent post-Chevron cases; Christensen v. Harris County, ${ }^{214}$ where the Court rejected the argument that it should, per Chevron, defer to interpretations first put forward in legal briefs, ${ }^{215}$ and Bates v. Dow Agrosciences, ${ }^{216}$ where the court declined to adopt a 2003 Bush administration interpretation of the extent to which the Federal Insecticide, Fungicide and Rodenticide Act (FIFRA) ${ }^{217}$ preempts state lawsuits concerning the "duty to warn." The Bush interpretation had rejected an earlier 2000 Clinton administration interpretation of FIFRA allowing such suits. ${ }^{218}$ Pierce is concerned that given the long time frame involved in effectuating statutory change, as well as in promulgating substantive regulations, "a newly-elected President with policy preferences that differ from those of his predecessor is unlikely to get most of his preferred policies approved by courts and in effect in his first term in office."219 He believes that positions put forward by a prior administration should not remain privileged during the first term of a newly-elected president. ${ }^{220}$ Similarly

of congress as an institution reflective of the public interest can be found in THOMAS E. MaNN \& Norman J. Ornstein, The Broken Branch: How Congress is Failing America and How to Get It BACK ON TRACK 212 (2006). The authors condemn the "gradual collapse of the center in Congress," asserting that parties now search for political success through "corrosive partisanship" leading to a decline in politicians "who care about compromise, product, and institutional health."

${ }^{212}$ Seidenfeld, supra note 178, at 100. See also Motor Vehicle Mfr's Ass'n of U.S., Inc. v. State Farm Mut. Auto. Ins. Co. 463 U.S. 29, 59 (1983),

The agency's changed view . . seems to be related to the election of a new President of a different political party ... A change in administration brought about by the people casting their votes is a perfectly reasonable basis for an executive agency's reappraisal of the costs and benefits of its programs and regulations. As long as the agency remains within the bounds established by Congress, it is entitled to assess administrative records and evaluate priorities in light of the philosophy of the administration.

(Justice Rehnquist concurring and dissenting, 463 U.S. 29, 59 (1983).

${ }^{213}$ Pierce, Richard J., Democratizing the Administrative State, GWU Law School Public Law Research Paper No. 173, 4, 10-17. (October 2005), abstract available at http://ssrn.com/abstract $=839227$ (last visited November 7, 2006).

${ }^{214}$ Christensen v. Harris Cty., 529 U.S. 576 (2000).

${ }^{215} \mathrm{Id}$. at 586.

${ }^{216}$ Bates v. Dow Agrosciences LLC, 544 U.S. 431 (2005). The case is discussed in Joseph Frueli, Pesticides, Preemption, and the Return of Tort Protection, 23 Yale J. on Reg. 299 (2006).

2177 U.S.C. 136 et seq (2000).

${ }^{218}$ Bates, 544 U.S. at 448.

${ }^{219} \mathrm{Id}$.

${ }^{220} I d$. at 15 . 
Justice Scalia has argued that Chevron deference should be applied as long as the expression of an agency's interpretation is authoritative, regardless if that opinion has not been through the formal "notice and comment" process. ${ }^{221}$ In Pierce's opinion, "Scalia's broader approach to Chevron would allow a President to get most of his preferred policies approved and in effect within a couple of years of taking office."222 In contrast to Scalia's majoritarian approach, Justice Souter views deference in Chevron as a function of agency expertise, reserved for situations where an agency's opinion is expressed more "formally," i.e., after formal "notice and comment" procedure. ${ }^{23}$

Furthermore, tracking the implications of this approach Elena Kagan has proposed to "link deference in some way to presidential involvement" 224 ratcheting up the level of deference according to the level of executive involvement. Following this logic, some have argued that Chevron requires a less deferential standard for independent agencies $^{225}$ which by constitutional tradition remain "free from executive control."226

Of course, the view that there should be little or no "drag" on the implementation of policy preferences put forth by a new administration conflicts directly with notions of rationality and expertise as lodestars for administrative behavior. While Chevron speaks to canons of statutory interpretation, not standards of judicial review, the majoritarian approach to Chevron regarding deference conflicts directly with the spirit of the so-called "hard look" doctrine of judicial review, ${ }^{227}$ as reflected in the State Farm $^{228}$ case--a spirit that placed burdens of rationality and reasoned explanation on new administrations seeking to change regulatory policy.

It is in this light that one must consider the comments of critics of the "democratic" explication of Chevron, such as Thomas Merrill, who has argued that the decision reflects "a doctrine for Jacobeans: [that] the results of a single Presidential election are a sufficient cause for wholesale modifications in the law, with no offsetting

${ }^{221}$ Christensen, 529 U.S. at 591 (Scalia, J. concurring in part and concurring in judgment).

${ }^{222}$ Pierce, supra note 213, at 17.

${ }^{223}$ United States v. Mead Corp., 533 U.S. 218, 228 (2001)(quoting Skidmore v. Swift \& Co., 323 U.S. 134, 139-40 (U.S. 1944)).

${ }^{224}$ Elena Kagan, Presidential Administration, 114 HaRv. L. REv. 2245, 2376, 2378 (2001). In that regard she would distinguish "between actions taken by executive branch agencies and those taken by independent commissions." Id. at 2376.

${ }^{225}$ Randolph J. May, Defining Deference Down: Independent Agencies and Chevron Deference, 58 ADMIN. L. REV. 429, 432 (2006).

${ }^{226}$ Humphrey's Ex'r v. United States, 295 U.S. 602, 628 (1935).

${ }^{227}$ See supra note 178 , and accompanying text.

${ }^{228}$ Motor Vehicle Mfrs. Ass'n, 463 U.S. 29. 
incentive for stability or protection of reliance interests." 229 They have sought other explanations. One justification focused on the need to promote regulatory uniformity through a kind of interpretative Occam's Razor which allocated interpretative responsibility to the agency thus "enhanc[ing] the probability of uniform rational administration of the laws" rather than relaying on the diverse interpretations of 156 federal appellate judges and 12 circuit courts. ${ }^{230}$ A second justification sought to resurrect the New Deal notion of experts, drawing on language in Chevron itself which states "that those with great expertise and charged with responsibility for administering the provision would be in a better position [than Congress] to do so."231

Today, however, we see a seeming retrenchment of Chevron or, at least, a "domestication" of the text's political reach. ${ }^{232}$ This can be best seen in United States v. Mead, ${ }^{233}$ where the Court refocused the Chevron grundnorm on the requirement of congressional intent, generally ignoring the larger theoretical rationales reflected by and in the accountability "project" of administrative law. Thomas Merrill presaged this development as early as 1992, when he noted that "the failure of Chevron to perform as expected can be attributed to the Court's reluctance to embrace the draconian implications of the [Chevron] doctrine for the balance of power among the branches, and to practical problems generated by its all-or-nothing approach to the deference question." 234

On this view, we cannot presume that "accountability" empowers the executive branch to make interpretive judgments unless the legislative (with its own claims to democratic legitimacy) so approves. Therefore, "accountability" alone cannot fully resolve the challenge of the relationship between courts and agencies in the administrative state.

\footnotetext{
${ }^{229}$ Merrill, supra note 200, at 1028.

${ }^{230}$ Peter Strauss, One Hundred Fifty Cases Per Year: Some Implications of the Supreme Court's Limited Resources for Judicial Review of Agency Action, 87 Colum. L. Rev. 1093, 1121 (1987).

${ }^{231}$ Chevron, supra note 192 at 865.

${ }^{232}$ Ronald M. Levin, The Anatomy of Chevron: Step Two Reconsidered, 72 CHI.-KeNT. L. Rev. 1253 (1997).

233535 U.S. 218 (2001); see also Lisa Bressman, How Mead has Muddled Judicial Review of Agency Action, 58 Vand. L. Rev. 1443 (2005)[hereinafter Bressman, Mead](providing a "narrow" reading of Mead).

${ }^{234}$ Merrill, supra note 200, at 970.
} 
I should note here a powerful alternate reading of Chevron based on a view of administrative law different from my own. In a series of recent articles, ${ }^{235}$ Lisa Bressman argues that "the relationship between deference and democracy is more complicated than we have thought." ${ }^{236}$ Indeed, she mounts a frontal assault on the view that legitimacy in administrative law derives from a successful effort to overcome administrative law's 'democratic deficit.' Instead, she argues that it is "erroneous" to believe that "the constitutional structure is committed foremost to promoting political accountability." 237 Rather, she argues that "political accountability alone does not adequately discipline the exercise of governmental lawmaking authority." ${ }^{238}$ True legitimacy, she believes, comes from control of arbitrary government conduct though rule of law practices. ${ }^{239}$ In her view, "procedural formality also is necessary to guard against, among other things, even the 'authoritative' production of unfair, inconsistent, or arbitrary law." 240 Such "[p]rocedural formality, whether imposed under constitutional law or administrative law, always has been a necessary feature of governmental legitimacy."24i

This approach results in a different reading of Chevron and its progeny. Bressman would not justify Chevron's allocation of decisional power to agencies on the grounds that the executive branch (e.g. the president) represents electoral accountability. Rather, she would argue that Chevron deference is justified as a way for the judiciary to monitor against arbitrary behavior by agencies. ${ }^{242}$

Bressman's rejection of democracy as the source of political legitimacy reflects skepticism about the importance of popular will in our constitutional system. Like her colleague Edmund Rubin, she would reject "the assumption that elections promote

${ }^{235}$ See Bressman, Deference, supra note 208; Bressman, Mead, supra note 233; Bressman, Judicial Review, supra note 67; Bressman, Beyond Accountability, supra note 50; and Lisa Schultz Bressman \& Michael P. Vandenbergh, Inside the Administrative State: A Critical Look at the Practice of Presidential Control, Vanderbilt Public Law Research Paper No. 06-07, Mich. L. Rev. Vol. 105 (2006).

${ }^{236}$ Bressman, Deference, supra note 208, at 1.

${ }^{237}$ Bressman, Judicial Review, supra note 67, at 1658-59.

${ }^{238}$ Bressman, Mead, supra note 233, at 1449.

${ }^{239}$ See Bressman, Beyond Accountability, supra note 50, at 532 (charging that Whitman v. American Trucking Ass'ns "signaled a rule of law deficit that could only be made up with administrative standards."). See also Edward Rubin, The Myth of Accountability and the Anti Administrative Impulses, 103 Mich. L. REv. 2073, 2077 (2004-5).

${ }^{240}$ Bressman, Mead, supra note 233, at 1449.

${ }^{241} \mathrm{Id}$.

${ }^{242} \mathrm{Id}$. at 1450. 
accountability," arguing instead that a "relationship to accountability, although not entirely absent, is a relatively minor aspect of the electoral process." ${ }^{243}$ Her somewhat elitist approach suggests that mere democracy is not enough; one must have deliberative and rational democracy as well.

I disagree. While I am all for deliberative democracy, ${ }^{244}$ as it creates a better democracy, political legitimacy comes from the people-drunk or sober. Political legitimacy is key. Why? Because it provides a surrogate for democratic legitimacy. What Bressman ignores is that you can have better and worse democracies, democracies with strong traditions of the rule of law (and accountability), and those with higher levels of political cronyism.

Furthermore, there is no need to be forced by Bressman into the fateful choice between democratic values, which by their nature demand political accountability, and rule of law values as the touchstone of legitimacy. Rather, I would suggest that the pressure for accountability in administrative law reflects an effort to substitute for the lack of democratic legitimacy. ${ }^{245}$ It is a functional surrogate that stands in for democratic legitimacy. Therefore, as I have argued earlier ${ }^{246}$ the accountability project is yet another effort to substitute for administrative law's democratic "deficit," not a rejection of the "deficit" problem.

Bressman's approach, then, need not be inconsistent with the analysis in this paper. Indeed, there is a sense in which Bressman herself is not fully opposed to this view. Her "domesticated" understanding of Chevron would limit deference in situations where the executive branch acts in ways that do not reflect full and open democratic debate. Despite her best efforts, Bressman's focus remains on democratic legitimacy-she diverges only in that she seeks to achieve this end by concentrating solely on the rationality project, while dismissing the advantages of accountability, transparency, and participation. I would submit that it is perilous to ignore the benefits to be reaped from each of these approaches, as no one approach has demonstrated an ability to bring administrative law fully in step with the nation's traditional democratic principles (a fundamental part of our national identity).

\footnotetext{
${ }^{243}$ See Rubin, supra note 239, at 2077.

${ }^{244}$ See Fishkin, supra note 166.

${ }^{245}$ See supra text accompanying notes 52-89.

${ }^{246} \mathrm{See}$ the U.S. Constitution, Article I.
} 


\section{Conclusion}

Where does all this leave us? The four projects discussed above all reflect the challenge of securing legitimacy for the American administrative process. All are efforts to provide some kind of substitute for the perceived democratic deficit in American administrative law. All can only provide partial recompense. Their almost dialectical process of rise and fall suggests that the "quest for a "unified' theory of the administrative state," is illusory at best. ${ }^{247}$ It is no surprise that, in Richard Stewart's words, "Administrative law will continue to be evolutionary and strongly conserving in character. The several existing forms and remedies will continue to be maintained, although their application may change, even as new ones are developed and added."248

However nostalgic one might be for a more modest government sector, in the end, we must live with the modern administrative state. As Justice Breyer has noted, "to achieve our democratically chosen ends in a modern populous society requires some amount of administration, involving administrative, not democratic, decisionmaking. To achieve those same ends in a technologically advanced society requires expertise." 249

However, the $21^{\text {st }}$ century will no doubt raise all sorts of new issues and innovations for administrative lawyers to consider, including issues as diverse as the role of government corporations; the role of public-private partnerships; the extension of government rules of process to private sector activities that have a large state regulatory context; the movement from command-and-control rules to performance rules; new efforts to bring arbitration and mediation into the administrative process; the proper treatment of informal adjudication; and new approaches to reinvigorating the arguably "ossified" rulemaking process.

\footnotetext{
${ }^{247}$ Seidenfeld, supra note 178 . Reuel Schiller argues that the "incoherence that has developed in administrative law" derives not from the legitimacy challenge but from "the decline of legal liberalism and the political ascendancy of a Republican party" reflecting "a laissez-faire. Antistatist ideology." Reuel E. Schiller, Enlarging the Administrative Polity: Administrative Law and the Changing Definition of Pluralism, 1945-1970, 53 VAND. L. REv. 1389, 1451-52 (2000).

${ }^{248}$ Richard B. Stewart, Essay: Administrative Law in the Twenty First Century, 78 N.Y.U.L. Rev. 437,453 (2003).

${ }^{249}$ Hon. STEPHen Breyer, Active Liberty 102-03 (2005).
} 
The central problem never changes. Whatever these innovations propose to do in terms of efficiency or equity they will need to address the problem of legitimacy. Countries like France and perhaps Israel, can appeal to the "technocratic" model. However, for Americans, the appeal to experts will not suffice and for that reason efforts to ensure the legitimacy of the American administrative state will continue to develop and evolve. 